\title{
New organic-walled dinoflagellate cysts from the Cenomanian to Maastrichtian of the Trunch borehole, UK
}

\author{
MARTIN A. PEARCE \\ Statoil ASA Sandsliveien 90, Sandsli, Bergen, N-5254, Norway \\ (e-mail: mpear@statoil.com)
}

\begin{abstract}
A high-resolution palynological study of Cenomanian to Maastrichtian chalks from the Trunch borehole (southeastern UK) has revealed twelve new species and one new subspecies of organic-walled dinoflagellate cysts: Alterbidinium ioannidesii sp. nov., Cassiculosphaeridia alta sp. nov., Chatangiella eminens sp. nov., Cordosphaeridium catherineae sp. nov., Eatonicysta exilis sp. nov., Eatonicysta? mutabilireta sp. nov., Hystrichostrogylon robustum sp. nov., Membranilarnacia wilsonii sp. nov., Nelsoniella incomposita sp. nov., Odontochitina diducta sp. nov., Spiniferites jarvisii sp. nov., Spiniferites multispinulus sp. nov. and Spiniferites ramosus aquilus subsp. nov. Two new genera, Dimidium gen. nov. and Whitecliffia gen. nov. are described to necessitate the new combinations (with a former name in parentheses) of Dimidium striatum gen. et comb. nov. (Pterodinium? striatum) and Whitecliffia spinosa gen. et comb. nov. (Thalassiphora? spinosa). J. Micropalaeontol. 29(1): 51-72, May 2010.
\end{abstract}

KEYWORDS: new species \& genera, Trunch borehole, dinoflagellate cysts, taxonomy, Upper Cretaceous

\section{INTRODUCTION}

Following their inception in the Triassic, dinoflagellate cysts from the Upper Cretaceous remain arguably the least well known, with many undescribed and poorly understood forms (Costa \& Davey, 1992). Recent studies on Upper Cretaceous sequences have described many new taxa (Prössl, 1990; Kirsch, 1991; Schiøler, 1993, Slimani, 1994, 2001; Schiøler et al., 1997, Prince et al., 1999, 2008; Pearce et al., 2003) but focus on sections with a relatively short stratigraphic range and/or with a relatively wide sampling interval. The palynology of a continuous Cenomanian to lower Maastrichtian core at Trunch (southeast UK; Fig. 1), the most extensive section from onshore UK, has been studied at a 1-2 m sample resolution and yielded two new genera, twelve new species and one new subspecies of organic-walled dinoflagellate cysts, which are described here.

\section{MATERIALS AND METHODS}

The Trunch borehole (Norfolk, UK; TG 2933 3455; N 52 ${ }^{\circ} 51^{\prime} 34^{\prime \prime}$ E $01^{\circ} 24^{\prime} 19^{\prime \prime}$; Fig. 1) was continuously cored in 1975 by the British Geological Survey (BGS; then the Institute of Geological Sciences) to sample the Chalk at its most complete development in Britain. The 10-inch diameter core recovered a thick Quaternary cover and $468 \mathrm{~m}$ of Cenomanian-lower Maastrichtian Chalk (Wood et al., 1994), including $246 \mathrm{~m}$ of Campanian strata. The chalk samples from the borehole were taken from composite bags of $10 \mathrm{~cm}$ intervals, no cut round of core was preserved. Palynological processing techniques follow those of Pearce et al. (2003). Graphic logs of the core were drawn by Jarvis et al. $(2002,2006)$ based on the lithostratigraphy and macrobiostratigraphy of Gallois \& Morter (1976) and Wood et al. (1994), and form the basis of the borehole stratigraphy shown in Figure 2.

\section{SYSTEMATIC DESCRIPTIONS}

Division Dinoflagellata (Bütschli, 1885) Fensome et al., 1993

Subdivision Dinokaryota Fensome et al., 1993

Class Dinophyceae Pascher, 1914
Subclass Peridiniphycidae Fensome et al., 1993

Order Gonyaulacales Taylor, 1980

Suborder Gonyaulacineae (Autonym)

Family Gonyaulacaceae Lindemann, 1928

Subfamily Cribroperidinioideae Fensome et al., 1993

Genus Cordosphaeridium Eisenack, 1963a

Type species. Cordosphaeridium inodes (Klumpp, 1953: 391, pl. 18, figs 1-2) Eisenack, 1963a

Cordosphaeridium catherineae sp. nov. (Pl. 1, figs 10-13; Fig. 3)

Derivation of name. In honour of Dr Catherine Emma Stickley, University of Tromsø (Norway), for her contributions to integrated palynological/diatom studies of both hemispheres.

Diagnosis. A species of Cordosphaeridium with taeniate, solid, fibrous processes that are widest proximally, narrow medially before dividing into 2-5 isolated processes of constant width that terminate in a bifurcation.

Holotype. MPK 13889; e/f ref: R51/2; Plate 1, figs 10-13; lodged at the British Geological Survey, Kingsley Dunham Centre, Keyworth, Nottingham, UK.

Type locality and horizon. Trunch borehole, Norfolk, UK; 270.9-271.0 m, Burnham-Flamborough Chalk (undifferentiated), low Gonioteuthis quadrata Zone (mid-lower Campanian).

Description. Medium-sized, chorate dinoflagellate cyst with a sub-spherical body. Wall two-layered comprised of an endophragm and fibrous periphram that are closely appressed. Taeniate intratabular processes arise from the periphragm and appear to be solid. Processes are widest proximally (up to $14 \mu \mathrm{m}$ ), narrow medially where $2-5$ isolated processes, with a relatively constant width $(1 \mu \mathrm{m})$, are developed and terminate distally in a bifurcation. Proximal process width is directly proportional to the size of the corresponding paraplate such that 


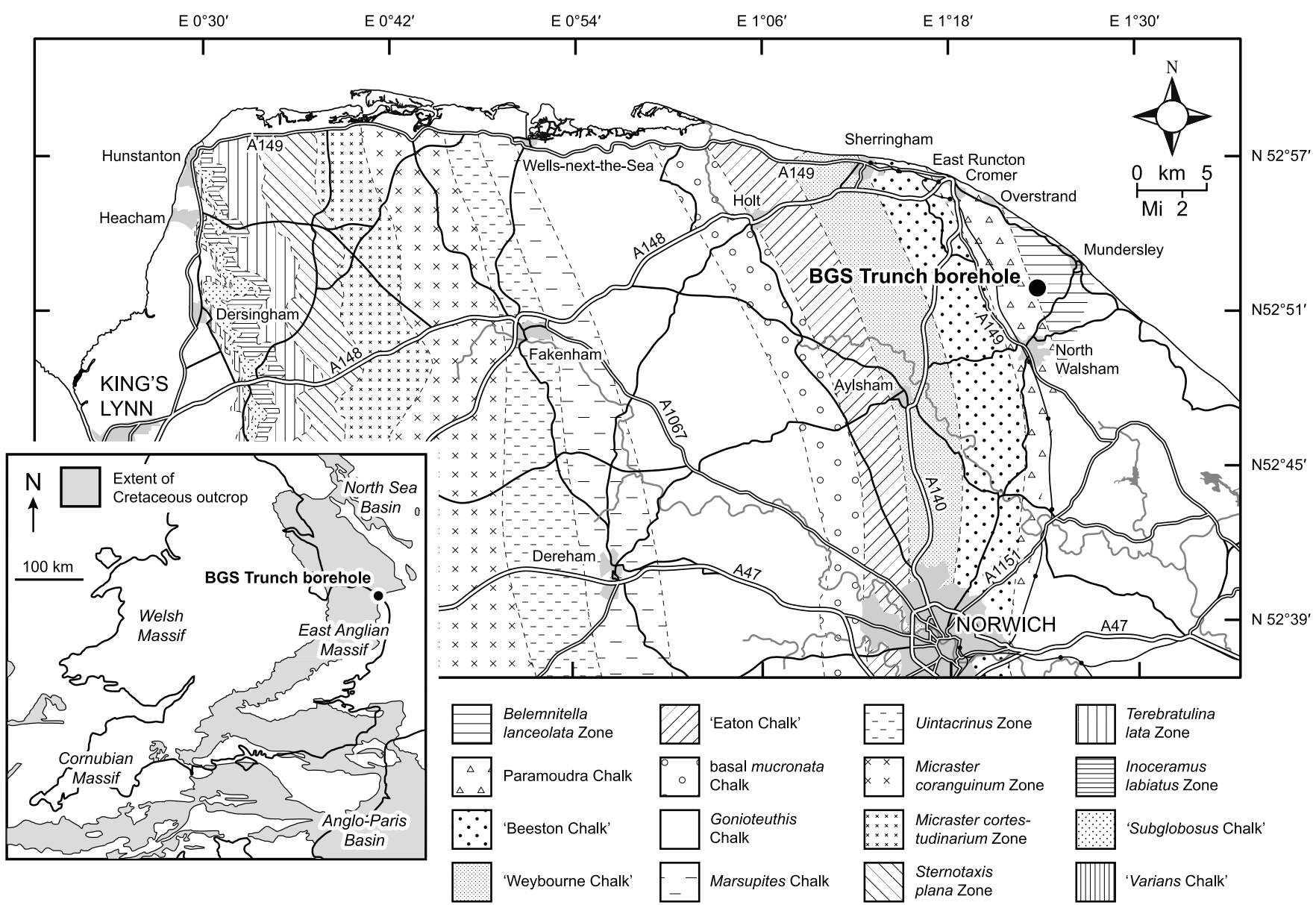

Fig. 1. Location map of the BGS Trunch borehole. Lithostratigraphy and macrofossil zones taken from Peake \& Hancock (1961). Inset map modified from Rawson (1992).

the largest processes occupy the larger reflected paraplates. As a result, the pre- and postcingular processes are the widest and the process occupying the $1^{\prime \prime \prime \prime}$ paraplate at the antapex is slender and typically the longest $(33 \mu \mathrm{m})$; the parasulcal processes do not vary significantly in width. Occasionally, two processes may occur on a single paraplate, particularly $4^{\prime \prime \prime}$. Twenty-four to twenty-six processes define the paratabulation $4^{\prime}, 6 "$, 5-6c, $5-6^{\prime \prime \prime}, 1 \mathrm{p}, 1^{\prime \prime \prime}, 2 \mathrm{~s}$ (as?, ras?; Fig. 3). The archaeopyle is precingular (Type 1P, operculum detached) and formed by the loss of the third precingular paraplate $\left(3^{\prime \prime}\right)$.

Dimensions. Holotype: central body (w/l) $43 \times 42 \mu \mathrm{m}$, process length $(\max ) 33 \mu \mathrm{m}$; range: central body (w/l) $35(45.1) 50 \times$ $32(40.7) 51 \mu \mathrm{m}$, process length $(\max ) 18(21.8) 33 \mu \mathrm{m} .15$ specimens measured.

Stratigraphic range. Burnham-Flamborough Chalk (undifferentiated), high Uintacrinus socialis Zone (mid-upper Santonian) to the low Gonioteuthis quadrata Zone (mid-lower Campanian; Fig. 2).

Remarks. The species superficially resembles Florentinia Davey \& Verdier, 1973 but differs by possessing solid processes. Furthermore, according to Stover \& Evitt (1978), more than one process per paraplate may be present in Cordosphaeridium, as is the case with 4 " in C. catherineae sp. nov.

Comparison. Differs from other species of Cordosphaeridium that also possess wide bases by possessing long processes that become isolated medially. Although the processes in $C$. inodes (Klumpp, 1953: 391, pl. 18, figs 1-2) Eisenack, 1963a may be also taeniate, they are hollow and open distally. Cordosphaeridium fibrospinosum Davey \& Williams, 1966b (86, pl. 5, fig. 5) possesses broad processes with an ovoidal cross-section but lacks the isolated processes that develop distally. C. exilimurum Davey \& Williams, 1966b (87-88, pl. 11, fig. 2) possesses tubiform processes and is distinctively thin-walled.

\section{Subfamily Gonyaulacoideae (Autonym) Genus Hystrichostrogylon Agelopoulos, 1964}

Type species. Hystrichostrogylon membraniphorum Agelopoulos, 1964 (674, text-fig. 1).

\section{Hystrichostrogylon robustum sp. nov.} (Pl. 5, figs 4-7)

Derivation of name. From the latin robustus, meaning strong, powerful or firm referring to the nature of processes. 


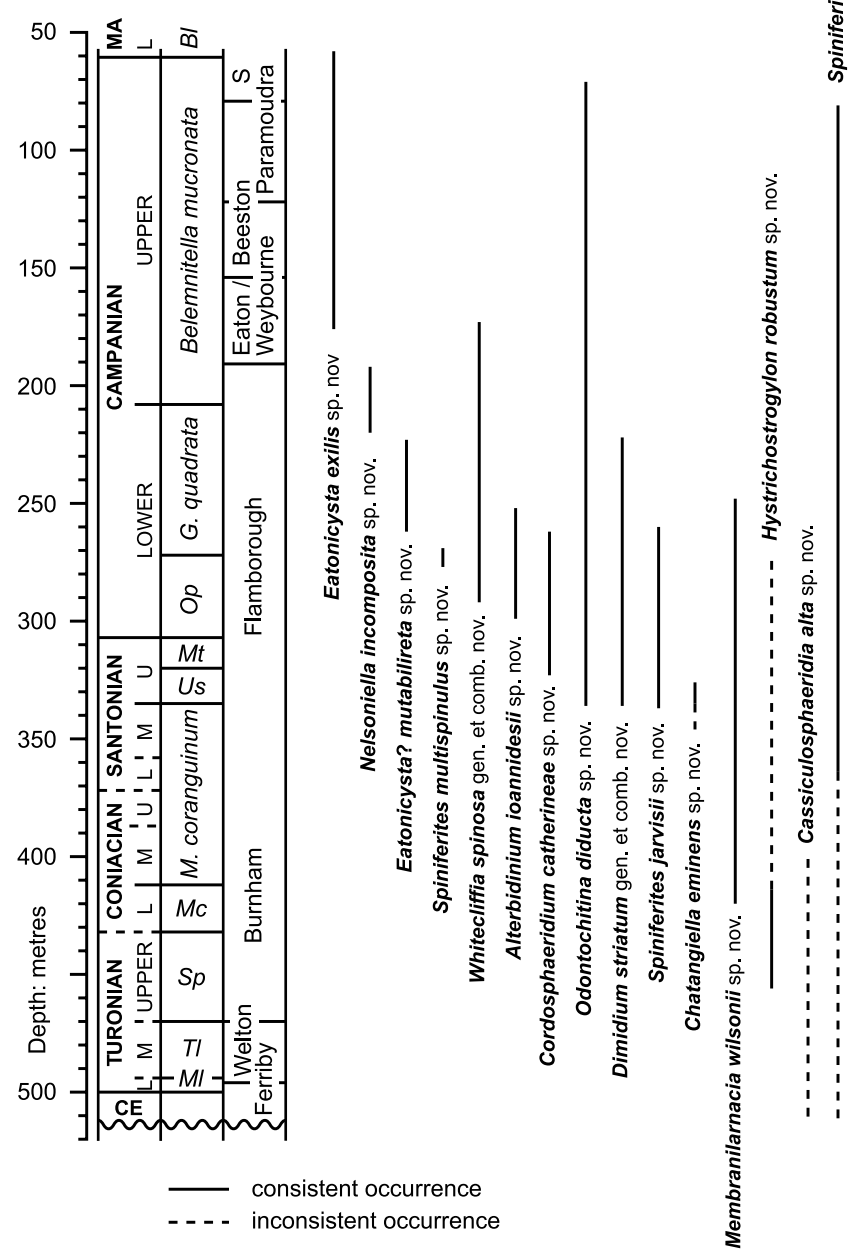

Fig. 2. Summary stratigraphic range chart of the species discussed in the text. Boundaries based on the graphic logs of Jarvis et al. $(2002,2006)$. Abbreviations - Bl, Belemnella lanceolata; G. quadrata, Gonioteuthis quadrata; M. coranguinum, Micraster coranguinum; Mc, Micraster cortestudinariuum; Ml, Mytiloides labiatus; Mt, Marsupites testudinarius; Sp, Sternotaxis plana; Tl, Terebratulina lata; Us, Uintacrinus socialis; L, lower; M, middle; U, upper; S, Sidestrand; CE, Cenomanian; MA, Maastrichtian.

Diagnosis. A species of Hystrichostrogylon with short, robust processes.

Holotype. MPK 13890; e/f ref: P40/2; Plate 5, figs 4-7; lodged at the British Geological Survey, Kingsley Dunham Centre, Keyworth, Nottingham, UK.

Type locality and horizon. Trunch borehole, Norfolk, UK; 432.3-432.4 m, Burnham-Flamborough Chalk (undifferentiated), high Sternotaxis plana Zone (high upper Turonian).
Description. Medium-sized, camocavate, spiniferate, dinoflagellate cyst. The central body episome is prolate ellipsoid and the hyposome is roughly spherical to minorly oblate ellipsoid. The wall is two-layered, comprised of a thin $(\sim 0.5 \mu \mathrm{m})$ and smooth endophragm and a thin $(\sim 0.5 \mu \mathrm{m})$ and smooth periphragm, which are separated ventrally and appressed elsewhere. Short ( $\sim 13 \mu \mathrm{m}$ long), stout trifurcating gonal processes (1-2 $\mu \mathrm{m}$ wide) and up to 3 bifurcating or simple intergonal processes arise from the periphram. Bi- and trifurcating processes terminate distally with a minute ( $1 \mu \mathrm{m}$ long) bifurcation. The longest processes are united proximally by a sutural crest and occur where the wall layers are appressed, and become shorter and lacking, or with much reduced, sutural crests where the wall layers are separated ventrally. As such, the paratabulation is incompletely developed. The archaeopyle is precingular (Type 1P, operculum detached) and formed by the loss of the third precingular paraplate (3"). A mid-ventral opisthopyle may be present in the periphragm.

Dimensions. Holotype: central body (w/1) $42 \times 52 \mu \mathrm{m}$, including pericoel $(\mathrm{w} / \mathrm{l}) 66 \times 53 \mu \mathrm{m}$, process length (max.) $13 \mu \mathrm{m}$; range: central body $(w / 1) 41(42.7) 46 \times 37(47.3) 53 \mu \mathrm{m}$, including pericoel $(w / 1) 46(56.7) 70 \times 44(53.2) 66 \mu \mathrm{m}$, process length (max.) 6(11) $16 \mu \mathrm{m}, 9$ specimens measured.

Stratigraphic range. Burnham-Flamborough Chalk (undifferentiated), high Sternotaxis plana Zone (high upper Turonian) to the low Gonioteuthis quadrata Zone (mid-lower Campanian; Fig. 2).

Comparison. Hystrichostrogylon robustum sp. nov. is most closely comparable with $H$. membraniphorum Agelopoulos, 1964 (674, text-fig. 1-2) but differs by possessing shorter processes (although there is a slight overlap in the 13-29 $\mu \mathrm{m}$ range for $H$. membraniphorum), and an incomplete but more strongly developed paratabulation. Hystrichostrogylon borisii Schiøler, 1993 (106, 108, pl. 1, figs 7-9; pl. 2, figs 1-3) and H. membraniphorum granulatum Heilmann-Clausen in Heilmann-Clausen \& Costa, 1989 (468, pl. 18, figs 1-3) have an ornamented endophragm, but which is smooth in $H$. robustum sp. nov. Differs from $H$. coninckii Heilmann-Clausen in Thomsen \& Heilmann-Clausen, 1985 (353, 355, pl. 7, figs 9-12; text-figs 10A-F), H. clausenii Bujak, 1994 (125, 127, pl. 1, figs 4-6) and H. holohymenium Islam, $1983(238,240$, pl. 3, figs 5-7) in the position of the pericoel.

\section{Genus Spiniferites Mantell, 1850}

Type species. Spiniferites ramosus (Ehrenberg, 1838, pl. 1, fig. 5 designated by Davey \& Williams, 1966a: 32) Mantell, 1854

\section{Spiniferites jarvisii sp. nov.}

$$
\text { (P1. 6, figs 2-5) }
$$

Derivation of name. In honour of Professor Ian Jarvis, Kingston University (London, UK) for his invaluable contribution to Cretaceous stratigraphy.

Diagnosis. A species of Spiniferites that possesses a thick endophragm that becomes thinner towards the paraplate margins. 

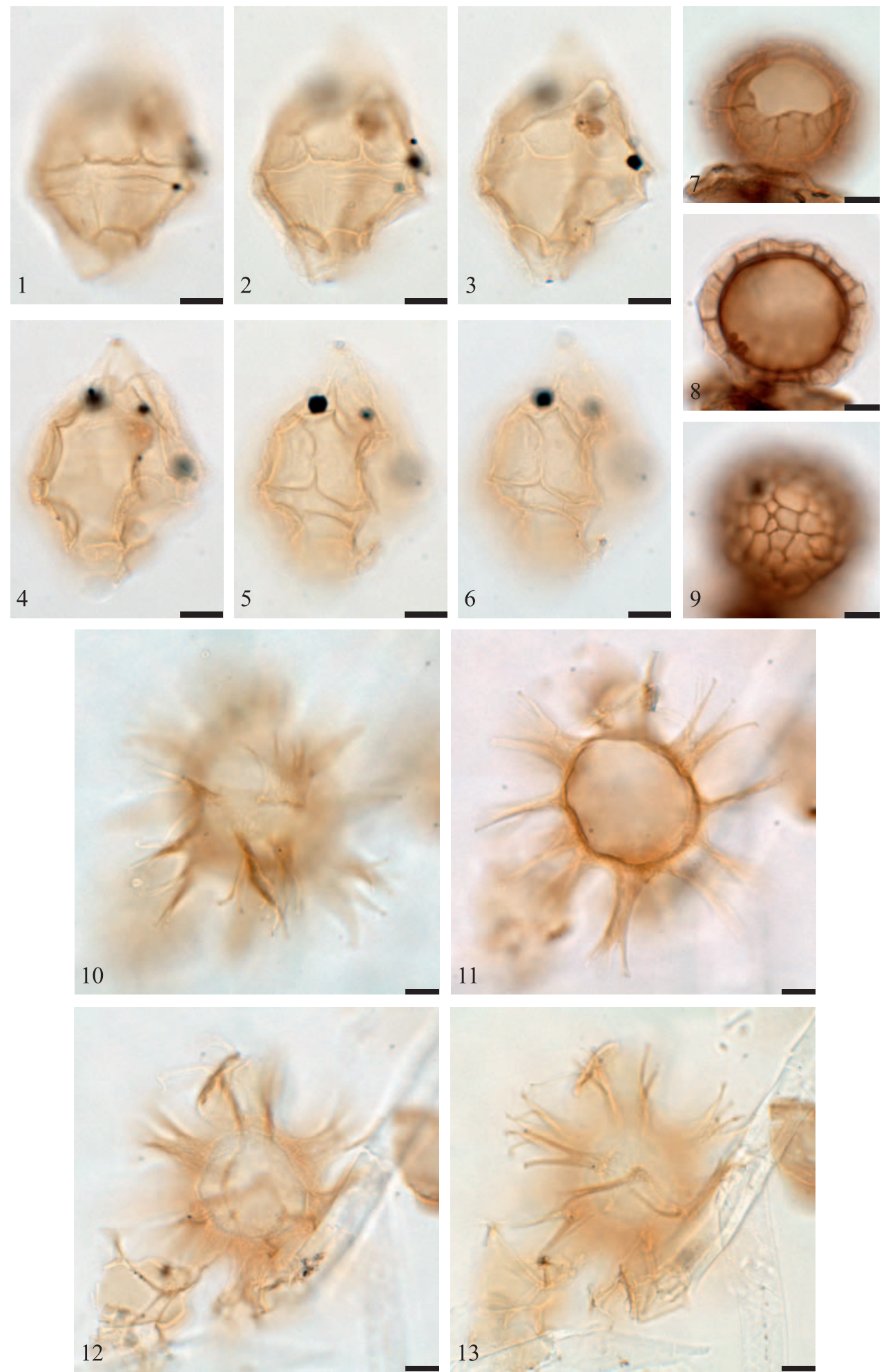

Explanation of Plate 1.

figs 1-6. Alterbidinium ioannidesii sp. nov. (holotype), MPK 13899, e/f ref: K38/3: 1, proximal dorsal view showing the well-developed parasutural ridges; 2-3, proximal mid-dorsal views clearly showing an omphalus; 4-5, internal mid-ventral view (reversed) showing the apical horn; 6, internal ventral view (reversed) showing the depressed parasulcus. figs 7-9. Cassiculosphaeridia alta sp. nov. (holotype), MPK 13897, e/f ref. P65: 7, external ventral view; 8, ambital view showing the crests; 9, internal dorsal view (reversed) showing the well-developed and irregular reticulum. figs 10-13. Cordosphaeridium catherineae sp. nov. (holotype), MPK 13889; e/f ref. R51/2: 10, internal dorsal view (reversed) showing the taeniate solid paracingular processes and pair of isolated processes on the 4"' paraplate; 11, ambital view showing the distinctive antapical process; 12, external mid-ventral view; 13, external ventral view. Scale bar $10 \mu \mathrm{m}$. 


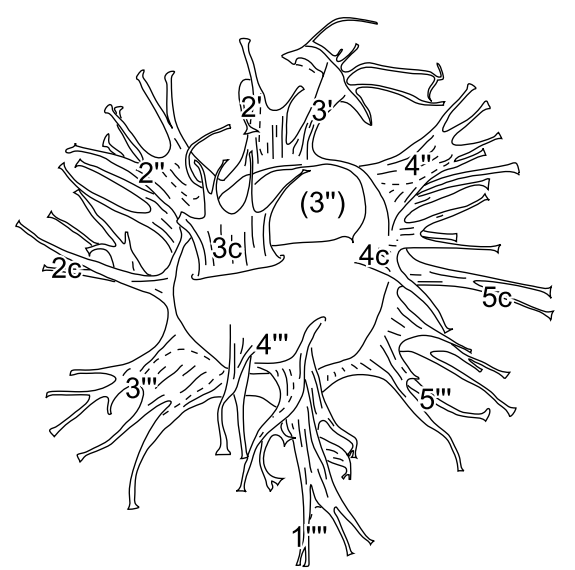

Fig. 3. Inferred paratabulation of the dorsal surface of Cordosphaeridium catherineae sp. nov. based on the arrangement of processes using Kofoid-notation, demonstrating that the cyst conforms to standard gonyaulacoid tabulation. Note the distinctive elongated antapical process.

Holotype. MPK 13891; e/f ref: X25/2; Plate 6, figs 2-5; lodged at the British Geological Survey, Kingsley Dunham Centre, Keyworth, Nottingham, UK.

Type locality and horizon. Trunch borehole, Norfolk, UK; 307.9-308.0 m, Burnham-Flamborough Chalk (undifferentiated), high Marsupites testudinarius Zone (high upper Santonian).

Description. Small to medium-sized spiniferate chorate dinoflagellate. The central body episome is prolate ellipsoid and the hyposome is roughly spherical to minorly oblate ellipsoid. The wall is two-layered, with a thick and smooth endophragm $(\sim 1.5 \mu \mathrm{m})$ that is thinned towards the margin of the paraplates and a smooth and thin periphragm $(\sim 0.5 \mu \mathrm{m})$ that forms the processes. The processes are gonal, approximately half the diameter of the central body in length, and trifurcate distally (with furcations up to $5 \mu \mathrm{m}$ in length) before terminating in a minute bifurcation (1-2 $\mu \mathrm{m}$ long). Parasutural crests are highest against the processes and up to $2 \mu \mathrm{m}$ high in between and clearly delineating the standard gonyaulacacean paratabulation. The paracingulum is distinctly laevorotatory by twice the width of the paracingulum; the parasulcus is straight and lacks clearly developed parasutural crests. The lateral margins of the sixth precingular paraplate taper apically and the paraplate appears to have a rectilinear contact with the apical series. The archaeopyle is precingular (Type 1P, operculum detached) and formed by the loss of the third precingular paraplate $\left(3^{\prime \prime}\right)$.

Dimensions. Holotype: central body (w/l) $31 \times 33 \mu \mathrm{m}$, process length (max.) $16 \mu \mathrm{m}$; range: central body (w/l) $31(36.6) 40 \times$ 33(41.8)50 $\mu \mathrm{m}$, process length (max.) 14(16.8)20 $\mathrm{m}, 10$ specimens measured.

Stratigraphic range. Burnham-Flamborough Chalk (undifferentiated), high Micraster coranguinum Zone (high middle Santonian) to the lower Gonioteuthis quadrata Zone (mid-lower Campanian; Fig. 2).
Comparison. Differs from other species of Spiniferites by possessing a thick endophragm that thins towards the margin of the paraplates. The mostly closely related species is Pterodinium crassimuratus (Davey \& Williams, 1966a: 39, pl. 1, fig. 11) Thurow et al., 1988 that also possesses the characteristic thinning of the endophragm, but differs in lacking processes that project beyond the parasutural crests.

\section{Spiniferites multispinulus sp. nov.} (P1. 7, figs 1-6)

Derivation of name. multi and spine referring to the two intergonal processes per septum.

Diagnosis. A species of Spiniferites consistently possessing two intergonal spines on the pre- and postcingular paraplates which are close to half the diameter of the central body in length.

Holotype. MPK 13892; e/f ref: P48; Plate 7, figs 1-6; lodged at the British Geological Survey, Kingsley Dunham Centre, Keyworth, Nottingham, UK.

Type locality and horizon. Trunch borehole, Norfolk, UK; 269.9-270.0 m, Burnham-Flamborough Chalk (undifferentiated), low Gonioteuthis quadrata Zone (mid-lower Campanian).

Description. Small to medium-sized, spiniferate chorate dinoflagellate with a prolate ellipsoid central body. The wall is two-layered, comprising a thin $(\sim 0.5 \mu \mathrm{m})$ and smooth endophragm and a thin $(\sim 0.5 \mu \mathrm{m})$ and smooth periphragm, the latter of which develops partially hollow processes. Trifurcating gonal and bifurcating intergonal processes are typically around half the diameter of the central body in length (with furcations up $6 \mu \mathrm{m}$ in length), and terminate in a minute bifurcation $(<1 \mu \mathrm{m}$ long). Gonal processes often possess a single vacuole at the mid-length. Two intergonal processes are consistently present on the lateral boundaries of the larger pre- and postcingular paraplates. The processes are united proximally by welldeveloped parasutural crests, highest against the processes and which may reach $6 \mu \mathrm{m}$ high in between, particularly those at the paracingulum, and clearly delineate the standard gonyaulacacean paratabulation. The paracingulum is weakly laevorotatory, typically by one paracingulum width; the parasulcus lacks clearly developed parasutures. The archaeopyle is precingular (Type 1P, operculum detached) and formed by the loss of the third precingular paraplate $\left(3^{\prime \prime}\right)$.

Dimensions. Holotype: central body $(\mathrm{w} / \mathrm{l}) 30 \times 37 \mu \mathrm{m}$, process length (max.) $15 \mu \mathrm{m}$; range: central body (w/l) $30(35.1) 42 \times$ $37(39.3) 43 \mu \mathrm{m}$, process length (max.) 12(14.9)18 $\mu \mathrm{m}, 10$ specimens measured.

Stratigraphic range. Burnham-Flamborough Chalk (undifferentiated), high Offaster pilula Zone (mid-lower Campanian) to low Gonioteuthis quadrata Zone (mid-lower Campanian; Fig. 2).

Remarks. Spiniferites multispinulus sp. nov. is most closely comparable to Spiniferites twistringiensis (Maier, 1959) Fensome 
et al., 1990. According to the original description of the junior synonym Hystrichosphaera ramosa subsp. multibrevis Davey \& Williams (1966a: 35-36), S. twistringiensis has by implication, short and solid processes that are much less than half the diameter of the central body in length, with a considerable variation in the number of intergonal processes (up to three). In contrast, S. multispinulus sp. nov. has partially hollow processes that are relatively longer and appears to be a stable form with a consistent number of processes. Furthermore, on inspection of the holotype of $H$. ramosus multibrevis (Davey \& Williams 1966a, pl. 4, fig. 6), few of the parasutures appear to possess more than one intergonal process (and this is also the case for the drawn specimen; (Davey \& Williams 1966a, fig. 9) and, therefore, it appears distinctly less 'spiny' than S. multispinulus sp. nov. Moreover, the crests are clearly higher in S. multispinulus, particularly between paraplates on the precingular and postcingular series, and vacuoles are not present on H. ramosus multibrevis. Finally, S. twistringiensis was recorded consistently from the Cenomanian to lower Maastrichtian in the Trunch borehole, while $S$. multispinulus sp. nov. is recorded only over an $8 \mathrm{~m}$ interval across the Offaster pilula/Gonioteuthis quadrata zonal boundary, making it a potentially useful marker. These observations are considered sufficient to treat $S$. multispinulus sp. nov. as a new species.

Comparison. Differs from all other species of Spiniferites by consistently possessing two intergonal processes on the lateral margins of the pre- and postcingular paraplates.

\section{Spiniferites ramosus aquilus $\mathrm{sp}$. nov.}

$$
\text { (P1. 7, figs 7-12) }
$$

Derivation of name. From the latin aquilus, meaning darkcoloured, blackish, referring to the densely reticulate endophragm.

Diagnosis. A species of Spiniferites possessing a densely and minutely reticulate periphragm imparting a distinctively dark aspect under transmitted light microscopy.

Holotype. MPK 13893; e/f ref: M56/2; Plate 7, figs 7-12; lodged at the British Geological Survey, Kingsley Dunham Centre, Keyworth, Nottingham, UK.

Type locality and horizon. Trunch borehole, Norfolk, UK; 415.9-416.0 m, Burnham-Flamborough Chalk (undifferentiated), high Micraster cortestudinarium Zone (high lower Coniacian).

Description. Small to medium-sized spiniferate chorate dinoflagellate. The central body episome is prolate ellipsoid and the hyposome is roughly spherical to minorly oblate ellipsoid. Wall two-layered, comprised of a thin endophragm $(\sim 0.5 \mu \mathrm{m})$, which is very finely reticulate such that the wall appears blackish under transmitted light microscopy. The periphragm is thin $(\sim 0.5 \mu \mathrm{m})$ and smooth from where hollow (at least proximally) processes are developed. The processes are short $(\sim 10 \mu \mathrm{m}$ long), gonal and trifurcate distally (3-4 $\mu \mathrm{m}$ in length) terminating in a minute $(<1 \mu \mathrm{m}$ long) bifurcation. The processes are united proximally by well-developed parasutural crests that are highest against the gonal processes and up to $4 \mu \mathrm{m}$ in between; clearly delineating the standard gonyaulacacean paratabulation. The paracingulum is distinctly laevorotatory by over twice the width of the paracingulum; the parasulcus is straight and lacking clearly delineated paraplates other than the posterior sulcal paraplate. The sixth precingular paraplate is distinctly triangular with a rectilinear contact with the apical series. The archaeopyle is precingular (Type 1P, operculum detached) and formed by the loss of the third precingular paraplate $\left(3^{\prime \prime}\right)$.

Dimensions. Holotype, central body $(\mathrm{w} / \mathrm{l}) 31 \times 36 \mu \mathrm{m}$, process length (max.) $10 \mu \mathrm{m}$; range, central body (w/l) $31(35) 38 \times$ 35(39)41 $\mu \mathrm{m}$, process length (max.) $9(9.8) 12 \mu \mathrm{m}, 10$ specimens measured.

Stratigraphic range. Ferriby Chalk, Mantellioceras mantellii Zone (lower Cenomanian) to the Paramoudra Chalk, high Belemnitella mucronata Zone (high upper Campanian; Fig. 2).

Remarks. The endocyst ornamentation is suggested to be reticulate rather than granulate since, where the cross-section of the surface can be seen (i.e. at the ambitus), the wall appears to have a negative ornament.

Comparison. Differs from Spiniferites ramosus reticulatus (Davey \& Williams 1966a: 38, pl. 1, figs 2-3) Lentin \& Williams, 1973 by possessing a more finely reticulate endophragm that results in a distinctively darkened aspect and a paratabulation clearly demarcated by the smooth parasutural crests.

\section{Subfamily Leptodinioideae Fensome et al., 1993 Genus Dimidium gen. nov.}

Type species. Gonyaulacysta striatum Clarke \& Verdier, 1967 (31, pl. 4, figs 11-13; pl. 5, fig. 15; text-fig. 12).

Derivation of name. From the latin dimidius meaning halved or divided in half, referring to the epicystal archaeopyle.

Diagnosis. Proximate dinoflagellate cysts with an epicystal archaeopyle, parasutural crests not (or rarely) exceeding $1 / 4$ body width, clearly expressing an exsert first apical homologue $\left(* 1^{\prime}\right)$, L-Type and sexiform paraplate patterns and slight dextral torsion.

Description. Medium-sized sub-spheroidal to oblate proximate dinoflagellate cyst lacking apical or antapical horns. The wall is single-layered and comprised of an autophragm that forms parasutural crests. The paratabulation is indicated by the low parasutural crests, less than $1 / 4$ body diameter in height, which conform to the standard gonyaulacoid formula 4', 6" , 6c, 5-6s (as, ras, rs, ls, ps), 6"', 1p, $1^{\prime \prime \prime \prime}$ (Fig. 4), and display an L-Type ventral pattern, and sexiform hypocystal paraplate arrangement. Slight dextral torsion exists such that the vertical midlines through the 3 " and $4^{\prime \prime \prime}$ paraplates are not in-line, and the $3^{\prime \prime} / 4$ " suture bisects the right lateral margin of the $5^{\prime \prime \prime}$ paraplate. The archaeopyle is polyplacoid epitractal (Type tAtP), the operculum is occasionally adnate ventrally, but more usually detached and contiguous. 


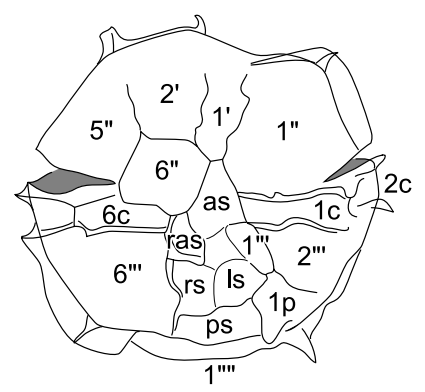

(a)

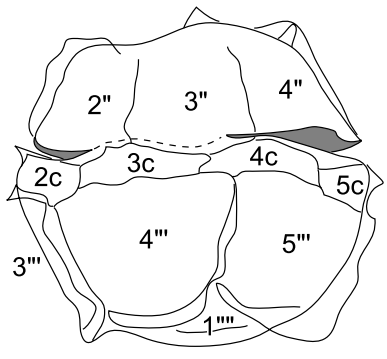

(b)

Fig. 4. Inferred tabulation of Dimidium striatum gen. et comb. nov., based on crest arrangement using Kofoid notation demonstrating that the cyst conforms to standard gonyaulacoid paratabulation: (a) ventral surface; (b) dorsal surface. The dashed line indicates the probable extent of the archaeopyle resulting in a ventrally adnate operculum.

Comparison. Dimidium most closely resembles Heslertonia Sarjeant, 1966 but differs in possessing parasutural crests that are much lower than $1 / 4$ body width. Ornamentation height (i.e. processes or crests) is probably an unsuitable generic level discriminator but the precedent stems back to an original difference between Pterodinium Eisenack, 1958 and Leptodinium Klement, 1960. However, Heslertonia is classified in the Order Gonyaulacales, but unassigned to a suborder or family (Fensome et al., 1993) since by implication the ventral and hyposomal paraplate configuration have not been determined. In contrast, Dimidium gen. nov. is clearly L-Type and sexiform with a slight dextral torsion. Since the orientation of the paraplates is well understood in Dimidium gen. nov., it is considered grounds to treat it distinct from Heslertonia, in the same way that Stover \& Evitt (1978) erected Impagidinium when the paratabulation of Pterodinium was unknown. Differs from Ctenidodinium Deflandre, 1939 in lacking anterior intercalary paraplates and from Dichadogonyaulax Sarjeant, 1966 in lacking a preapical structure (pr) separating the second from the fourth apical homologues. It differs from Dinopterygium Deflandre, 1935 by possessing a sexiform rather than quinqueform hypocystal paraplate pattern and in the position of the principal archaeopyle suture that is immediately anterior to the paracingulum rather than within the paracingulum. It differs from species of Impagidinium Stover \& Evitt, 1978, Leptodinium Klement, 1960 and Pterodinium Eisenack, 1958 primarily by possessing an epicystal archaeopyle.

Dimidium striatum (Clarke \& Verdier, 1967) gen. et comb. nov. (Pl. 2, figs 7-12; Pl. 3. figs 1-5; Fig. 4)

1967 Gonyaulacysta striata Clarke \& Verdier: 31, pl. 4, figs 11-13, text-fig. 12.

1969 Leptodinium striatum (Clarke \& Verdier) Sarjeant: 13. 1985 Leptodinium striatum (Clarke \& Verdier) Sarjeant: 72.

1981 Heslertonia rugula Yun: 72-73, pl. 8, figs 2a-b.

1981 Pterodinium striatum (Clarke \& Verdier) Yun: 12, pl. 8, figs $5 \mathrm{a}-\mathrm{b}, 6 \mathrm{a}-\mathrm{b}$

1986 Pterodinium striatum (Clarke \& Verdier) Yun; Jan du Chêne et al.: 274, pl. 88, figs 9-11.

1999 Pterodinium? striatum (Clarke \& Verdier) Yun; Prince et al.: 166.
Type species. As for the genus.

Holotype. Gonyaulacysta striata Clarke \& Verdier, 1967, plate 4, figs $11-13$.

Locality and horizon: Culver Cliff, Isle of Wight, UK; Sample CV26, Marsupites testudinarius Zone (upper Santonian).

Dimensions. Type material of Clarke \& Verdier (1967), holotype: overall (w/1): $55 \times 66 \mu \mathrm{m}$, height of crests (max.): $11 \mu \mathrm{m}$; range: overall (w/l): $40-55 \times 40-66 \mu \mathrm{m}$, height of crests (max.): 4-11 $\mu \mathrm{m}$.

Trunch borehole material, range: central body (w/l) $28(41.3) 50 \times 41(43) 46 \mu \mathrm{m}$, crest height $(\max ) 1(1.7) 2 \mu \mathrm{m}, 7$ specimens measured.

Stratigraphic range. Type section, as restudied by Prince et al. (1999): Broadstairs Chalk to Newhaven Chalk, high Micraster coranguinum Zone (high middle Santonian) to the Offaster pilula Zone (lower Campanian).

Trunch borehole material: Burnham-Flamborough Chalk (undifferentiated), high Micraster coranguinum Zone (high middle Santonian) to the high Gonioteuthis quadrata Zone (high lower Campanian; Fig. 2).

Remarks. Clarke \& Verdier (1967: 31-32) first described this species as: 'A species of Gonyaulacysta having no apical horn but possessing thin, often striate ledges ... plates smooth, bordered by ledges up to $5 \mu \mathrm{m}$ high ... the precingular archaeopyle is not an obvious feature'. In the measurement of an undisclosed number of specimens, the range of crest height was stated to be $4-11 \mu \mathrm{m}$, exceeding that stated in the description, and in the holotype the maximum crest height of $11 \mu \mathrm{m}$ is less than $1 / 4$ the shortest dimension of the central body (i.e. breadth $55 \mu \mathrm{m})$. Sarjeant (1969: 12) transferred the form to Leptodinium striatum without discussion, and emended the generic description: '. . . height of crests always less (and typically markedly less) than $1 / 4$ of shell width. A precingular single-plate archaeopyle ... may not be present'. A range of surface ornamentation was accepted (but he did not specify striate!). It is unknown which criteria Sarjeant used to justify the transfer, but it may be partly due to the relative height of the parasutural crests of Pterodinium, which, according to the basic description of Eisenack (1958: 395), were described only as 'broad'.

Yun (1981) emended the generic description of Pterodinium by quantifying crest height as $1 / 4$ of the body size, which are uniform in height on an individual specimen, and then proposed the combination Pterodinium striatum based on crest heights of 10-17 $\mu \mathrm{m}$. Yun's maximum crest height exceeds $1 / 4$ of the largest body dimension $(51 \mu \mathrm{m})$; however, it is not known if this is typical since the shortest crest height is also less than $1 / 4$ the shortest body diameter $(42 \mu \mathrm{m})$. The paratabulation was described with the formula: $3^{\prime}, 1 \mathrm{a}, 6^{\prime \prime}, 6 \mathrm{c}, 5^{\prime \prime \prime}, 1 \mathrm{p}, 1^{\prime \prime \prime}$; but critically the archaeopyle type was not recognized. From the same material, Yun (1981) also described a very similar new species Heslertonia regula, for otherwise identical species with an epicystal archaeopyle, possessing occasionally striate crests (stated to be up $13 \mu \mathrm{m}$ high). The average maximum crest height from 18 specimens of $9.7 \mu \mathrm{m}$ is less than $1 / 4$ the average shortest 

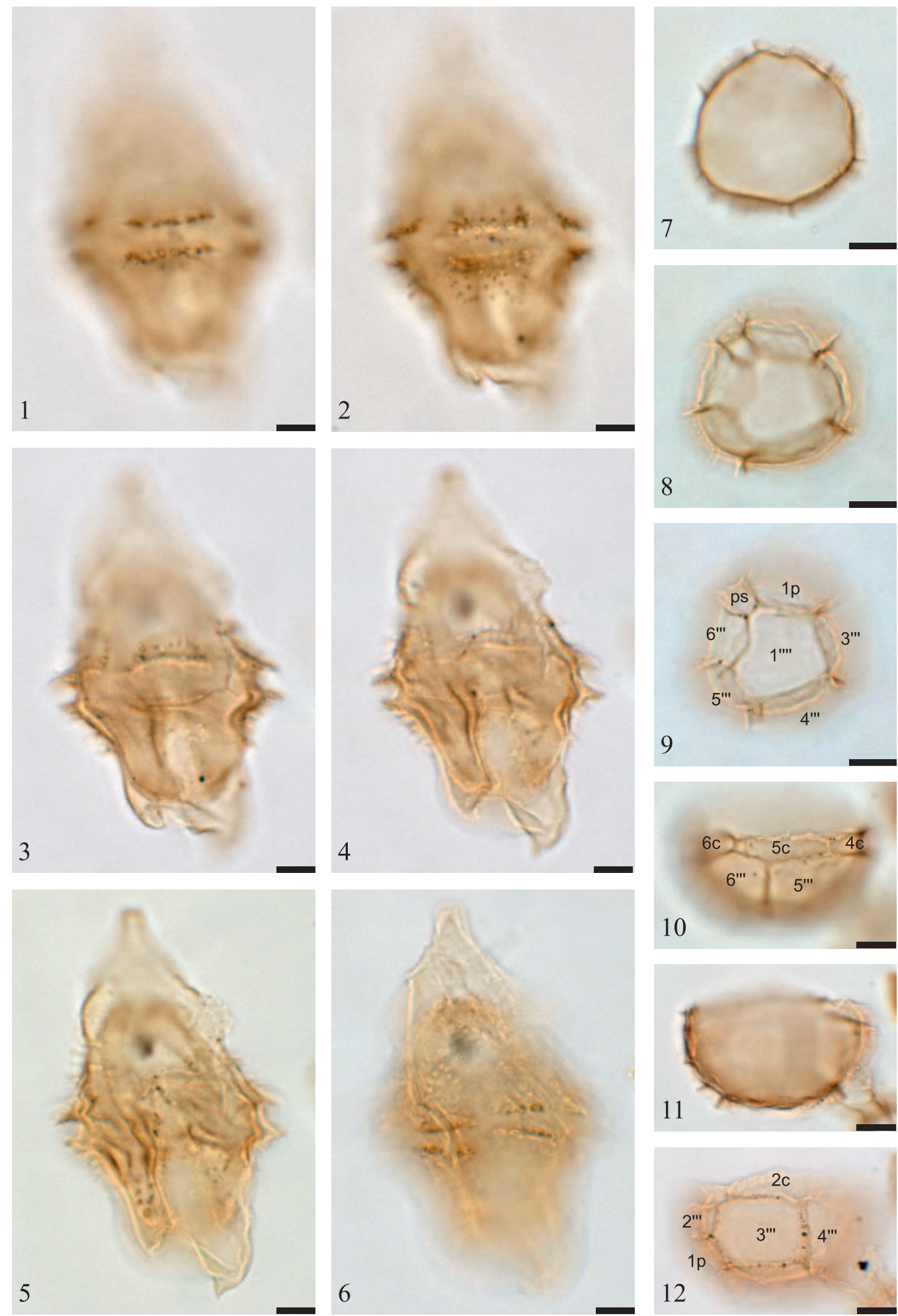

Explanation of Plate 2.

figs 1-6. Chatangiella eminens sp. nov. (holotype), MPK 13900, e/f ref. P60: 1, internal dorsal view (reversed) showing the fusing of some of the spines on the paracingulum; $\mathbf{2 - 3}$, internal mid-dorsal view showing the intratabular clustering of spines; $\mathbf{4}$, ambital view showing the peri-archaeopyle and the distinctively long spines on the lateral margins; 5, mid-ventral view showing the deeply depressed parasulcal area; 6, external ventral view showing the intratabular clustering of spines. figs 7-9. Dimidium striatum gen. et comb. nov.: 7, ambital view showing short paracingular spines; 8, external mid-hypocystal view; 9, external antapical view showing the 6-sided $1^{\prime \prime \prime \prime \prime}$ paraplate, and the clearly sexiform hypocystal configuration. figs 10-12. Dimidium striatum gen. et comb. nov.: 10, internal right lateral view (reversed); 11, ambital view showing the striated periphragm and short processes; 12, external left lateral view. Scale bar $10 \mu \mathrm{m}$ 

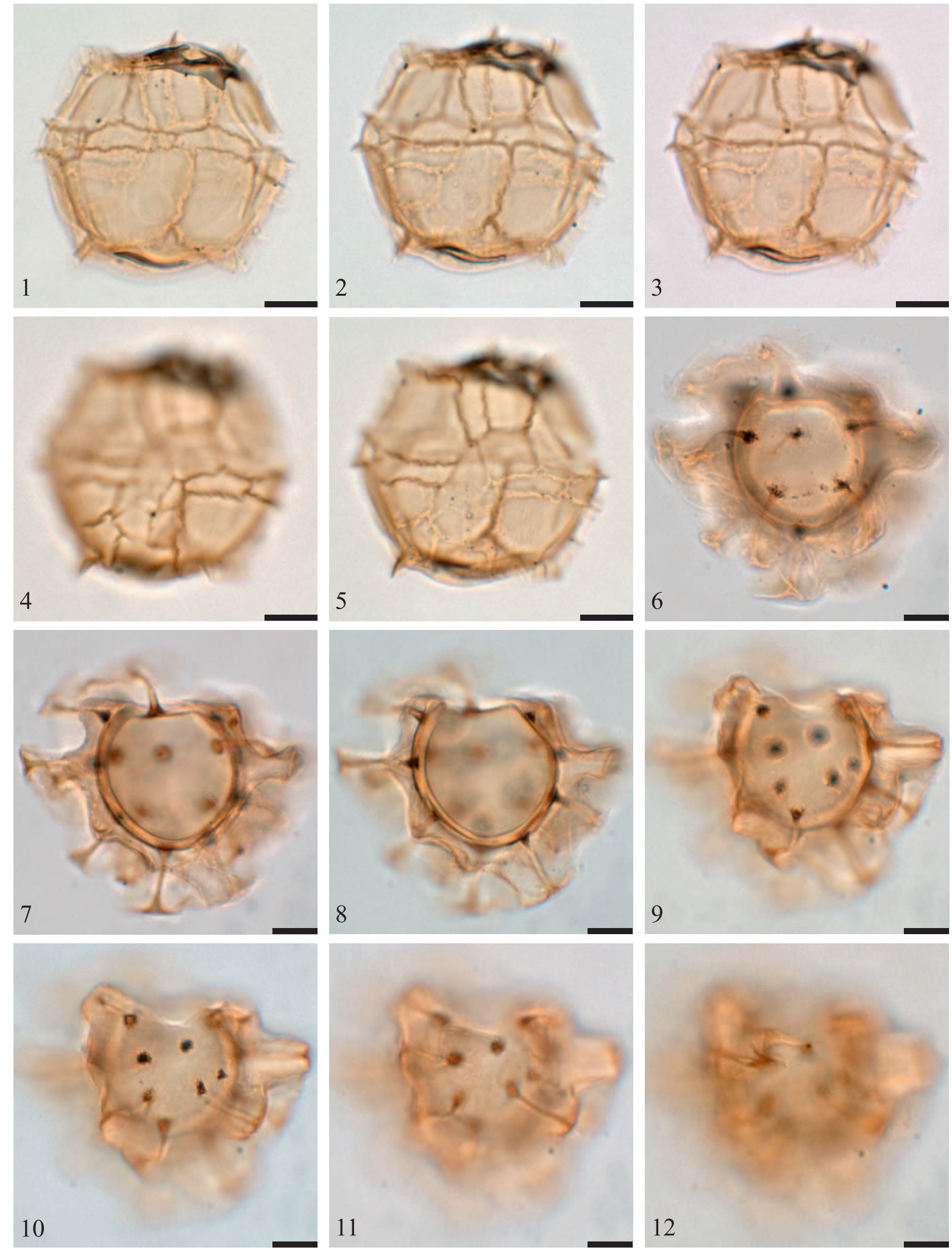

Explanation of Plate 3.

figs 1-5. Dimidium striatum gen. et comb. nov.: 1, external dorsal view showing the crenulated parasutural crests; 2 , external mid-dorsal view; $\mathbf{3}$, ambital view; 4, internal mid-ventral view (reversed) showing the well-differentiated plates in the parasulcus; 5, internal ventral view (reversed) showing the distinctive square-shaped 6" with a geniculate contact with 1' and 4' and L-Type ventral paraplate configuration. figs 6-12. Eatonicysta exilis sp. nov. (holotype), MPK 13894, e/f ref. O30: 6, external dorsal view; 7, external mid-dorsal view showing the solid processes; 8, ambital view; 9-11, internal mid-ventral views (reversed); 12, internal ventral view (reversed) showing the nature of the process endings. Scale bar $10 \mu \mathrm{m}$. 
body dimension of $48 \mu \mathrm{m}$ (although only just exceeds that in the holotype). Therefore, $H$. rugula is considered a synonym of $D$. striatum. The photograph of the detached epicyst of $H$. regula (Yun, 1981, pl. 8, fig. 8) suggests that D. striatum has an exsert first apical homologue $\left(*^{*} 1^{\prime}\right)$, typical of the subfamily Goniodomoideae (Autonym), but differs from others in that subfamily by possessing a sexiform rather than quinqueform hypocystal pattern.

Comparison. From the dimensions above, it is clear the crest heights of Dimidium striatum from the Trunch borehole are lower than those from the type material of Clarke \& Verdier (1967). Given the comparable first occurrences of the species, it would not be reasonable to differentiate these forms on crest height alone since crest height in many species is related to (supporting) processes' height, which has been shown to be a function of salinity (Ellegaard, 2000; Mertens et al., 2009; Rochon et al., 2009). This might be expected since the type area and the Trunch borehole are located in different basins. Significant salinity variations through the Upper Cretaceous at Trunch have been suggested by Whatley et al. (2003). Dimidium striatum gen. et comb. nov. appears to most closely resemble Heslertonia striata (Eisenack \& Cookson, 1960: 9, pl. 3, fig. 10-11) Norvick in Norvick \& Burger (1976), which also possesses a striate autophragm, but which differs in possessing stronger striations and higher parasutural crests that exceed $1 / 4$ body diameter. Furthermore, Heslertonia striata is most commonly recorded from the Albian and Cenomanian of Australia (i.e. Eisenack \& Cookson, 1960; Norvick \& Burger, 1976; Burger, 1980; McMinn \& Burger, 1986) but has been recorded in the Northern Hemisphere from Finland (Uutela, 1989), Germany (Below \& Kirsch, 1997) and Spain (Mao \& Lamolda, 1998; Lamolda \& Mao, 1999) but critically not above the lower Turonian. The disparate temporal range of $H$. striata and $D$. striatum gen. et comb. nov. provides supporting evidence for these as separate species.

\section{Genus Eatonicysta Stover \& Evitt, 1978}

Type species. Eatonicysta ursulae (Morgenroth, 1966: 20, pl. 3, fig. 11) Stover \& Evitt, 1978

Remarks. Williams \& Downie (1966) described two varieties of their Membranilarnacia reticulata (now a junior synonym of Eatonicysta ursulae). The more common $M$. reticulata var. a lacks paracingular processes (but possibly possesses parasulcal processes), while four paracingular processes were observed on $M$. reticulata var. b (the presence or absence of parasulcal processes was not mentioned). Although the presence or absence of paracingular processes is regarded as a generic-level characteristic in many genera, it is, therefore, clearly not the case in Eatonicysta. Stover \& Williams (1995) then emended the generic description of Eatonicysta as possessing a standard sexiform pattern with a paratabulation formula $4^{\prime}, 6^{\prime \prime}, 0-6 \mathrm{c}, 5^{\prime \prime \prime}, 1 \mathrm{p}, 1^{\prime \prime \prime}$, 0s.

Eatonicysta exilis sp. nov.

(P1. 3, figs 6-12)
Derivation of name. From the latin exilis meaning thin or meagre, referring to the thin nature of the ectophragm.

Diagnosis. A species of Eatonicysta possessing a thin entire ectophragm and six paracingular processes.

Holotype. MPK 13894; e/f ref: O30; Plate 3, figs 6-12; lodged at the British Geological Survey, Kingsley Dunham Centre, Keyworth, Nottingham, UK.

Type locality and horizon. Trunch borehole, Norfolk, UK; 93.9-94.0 m, Paramoudra Chalk, high Belemnitella mucronata Zone (high upper Campanian).

Description. Medium-sized chorate dinoflagellate cyst with an ovoidal central body. The body is two-layered with a smooth endophragm and periphragm, the latter of which forms processes that support a thin, loose and entire ectophragm. The processes are intratabular, solid, one per reflected paraplate and of consistent length. They are wide proximally (unconnected), narrowing at the mid-length, before widening and flaring distally. The paratabulation is indicated by intratabular processes that reflect the paraplate formula: 4'?, 6", 6c, 6"', 1p, 1"'", 2s? (as, ps). The paracingulum is indicated by an equatorial alignment of processes, and the parasulcus by a deep notch anterior to the anterior sulcal paraplate. The archaeopyle is apical (Type tA, operculum detached) and formed by the loss of all apical paraplates.

Dimensions. Holotype, central body (w/l; excluding archaeopyle) $33 \times 34 \mu \mathrm{m}$, processes' length (max.) $16 \mu \mathrm{m}$; range, central body (w/1; excluding archaeopyle) 26(34.6)43 × 18(33.2)44 $\mu \mathrm{m}$, processes' length (max.) 13(17.3)21 $\mu \mathrm{m} .10$ specimens measured.

Stratigraphic range. Eaton-Weybourne Chalk (undifferentiated), low Belemnitella mucronata Zone (low upper Campanian) to the Sidestrand Chalk, low Belemnitella lanceolata Zone (lower Maastrichtian; Fig. 2).

Remarks. Eatonicysta exilis sp. nov. possesses an anterior and posterior sulcal paraplate.

Comparison. Differs from Eatonicysta? mutabilireta sp. nov., Eatonicysta ursulae var. a sensu Williams \& Downie (1966), Membranilarnacia hapala (Schiøler \& Wilson, 1993: 346-347, pl. 2, figs 1-7; text-figs 12a-b) Lachkar \& Masure in Fauconnier \& Masure (2004) and M. pterococcoides (Wetzel, 1933b: 53, pl. 6, fig. 4) Eisenack, $1963 \mathrm{~b}$ by possessing paracingular processes. Differs from Eatonicysta ursulae var. b sensu Williams \& Downie (1966) by possessing 6 rather than 4 paracingular processes and in possessing an entire ectophragm.

\section{Eatonicysta? mutabilireta sp. nov.} (P1. 4, figs 1-6)

1991 Eatonicysta sp. A Heine, pl. 23, figs 10, 11.

Derivation of name. From the latin mutabilis meaning changeable, variable, inconstant and rete meaning a net, referring to the variable nature of the ectophragm. 
New dinoflagellate cysts from the Cenomanian to Maastrichtian, UK
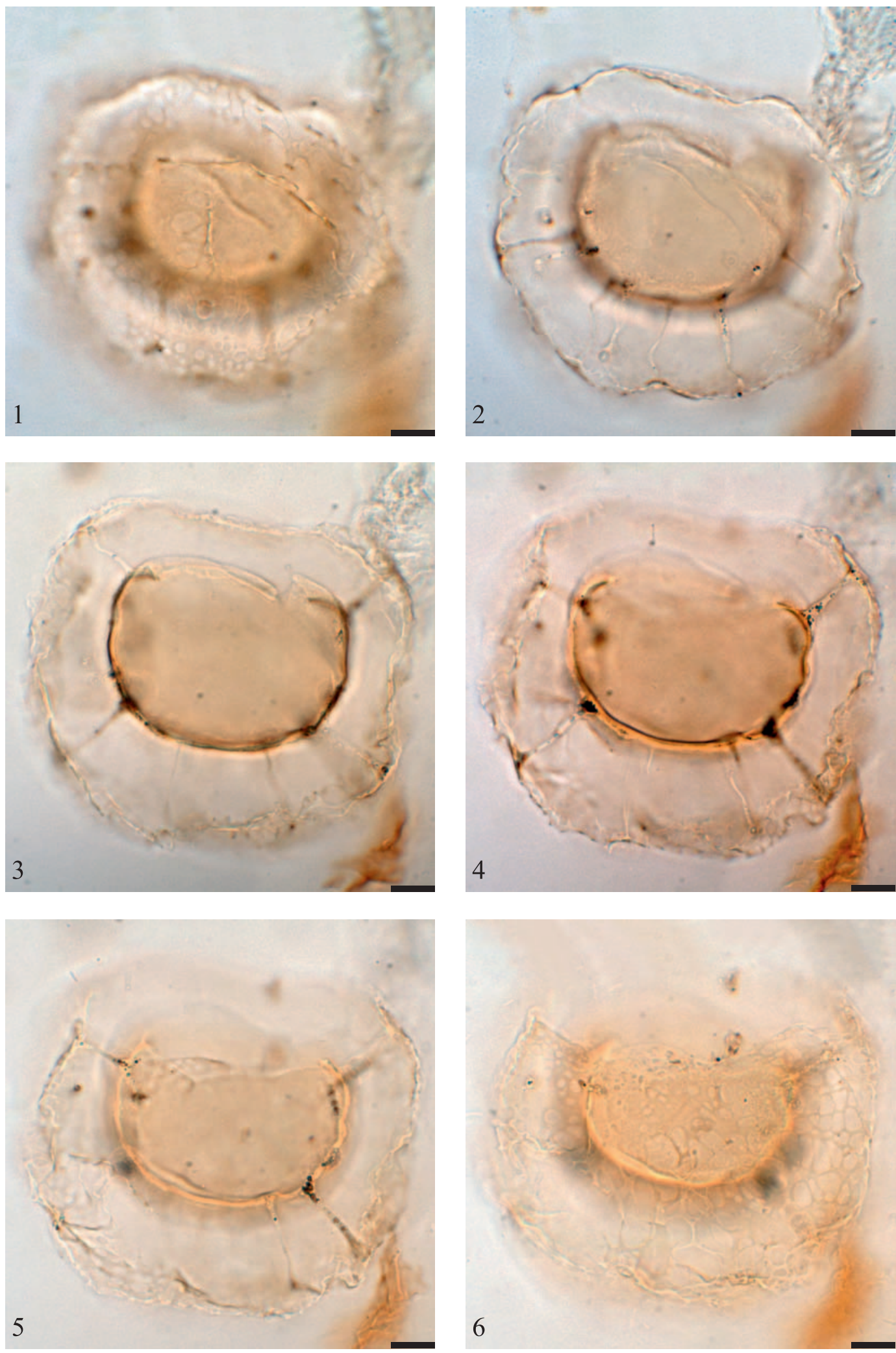

Explanation of Plate 4.

figs 1-6. Eatonicysta? mutabilireta sp. nov. (holotype), MPK 13895, e/f ref. R23/3: 1, internal view (reversed); 6, external view, the ventral and dorsal surfaces have not been distinguished. Scale bar $10 \mu \mathrm{m}$. 
Diagnosis. A species questionably attributed to Eatonicysta possessing a distinctive ectophragm modified by sub-rounded perforations of variable size to an irregular meshwork defined by rounded to (more usually) polygonal lumina.

Holotype. MPK 13895; e/f ref: R23/3; Plate 4, figs 1-6; lodged at the British Geological Survey, Kingsley Dunham Centre, Keyworth, Nottingham, UK.

Type locality and horizon. Trunch borehole, Norfolk, UK; 231.9-232.0 m, Burnham-Flamborough Chalk (undifferentiated), mid-Gonioteuthis quadrata Zone (high lower Campanian).

Description. Large chorate dinoflagellate cyst with an oblate spheroidal central body slightly dorso-ventrally compressed, but not lenticular. The body is two-layered and comprised of a smooth and thin endophragm and periphragm, the latter of which forms processes that support a thin and highly irregular ectophragm. The ectophragm completely surrounds the central body and is modified by sub-rounded to oval perforations of varying size to an irregular meshwork defined by rounded to (more usually) polygonal lumina. No indication of apical, lateral or antapical protuberances are observed in the cyst body. The processes are intratabular (but absent on the paracingulum and parasulcus) and solid, of consistent length, and near-constant width and unconnected at the base. The paratabulation is indicated by the position of the processes describing the formula: 4'?, 6", 0c, 6"', $1 \mathrm{p}, 1^{\prime \prime \prime}, 0 \mathrm{~s}$. The archaeopyle is apical (Type tA, operculum detached) and formed by the loss of all apical paraplates.

Dimensions. Holotype, central body (w/l; excluding archaeopyle) $60 \times 48 \mu \mathrm{m}$, processes' length (max.) $24 \mu \mathrm{m}$; range, central body (w/1; excluding archaeopyle) 51(62.2)76 × 44(50.4)67 $\mu \mathrm{m}$, processes' length (max.) 10(20.9)26 $\mu \mathrm{m} .10$ specimens measured.

Stratigraphic range. Burnham-Flamborough Chalk (undifferentiated), low Gonioteuthis quadrata Zone (mid-lower Campanian) to the high Gonioteuthis quadrata Zone (high lower Campanian; Fig. 2).

Remarks. The species is questionably attributed to Eatonicysta on the interpretation of the presumed degree of dorso-ventral compression. Due to the thin nature of the central body, this species is frequently found damaged, folded or mechanically compressed. Few specimens, (including the holotype) indicate some dorso-ventral compression, but much less strongly than genera in the Family Areoligeraceae.

Comparison. Differs from Eatonicysta exilis sp. nov., Membranilarnacia hapala (Schiøler \& Wilson, 1993: 346-347, pl. 2, figs 1-7, text-figs 12a-b) Lachkar \& Masure in Fauconnier \& Masure (2004) and M. pterococcoides (Wetzel, 1933b: 53, pl. 6, fig. 4) Eisenack, 1963 b by possessing a distinctly perforate rather than entire ectophragm. Eatonicysta? mutabilireta sp. nov. closely resembles the type species E. ursulae (Morgenroth, 1966: 20, pl. 3, fig. 11-12) Stover \& Evitt, 1978 but differs in the morphology of the ectophragm mesh. In E. ursulae, the mesh is usually uniform with usually polygonal lumina, while in $E$ ? mutabilireta sp. nov. the mesh is highly irregular and the lumina vary in size and shape (rounded to polygonal). Glaphyrocysta Stover \& Evitt, 1978 differs by being lenticular, strongly dorsoventrally flattened with an offset parasutural notch, and possessing annulate to arcuate penitabular process complexes. The ectophragm in E? mutabilireta, however, is very similar to that of Glaphyrocysta semitectum Bujak in Bujak et al., 1980 (46, 48, 50, pl. 14, figs 2-9; text-fig. 13) but differs by being completely developed. Species of Riculacysta Stover, 1977 also possess solid, normally isolated processes that support an ectophragm, but which differ by possessing ventrolateral processes that are longer than the lateral ones, and where the ectophragm is appressed or close to the autophragm dorsally.

\section{Suborder Ceratiineae Fensome et al., 1993 \\ Family Ceratiaceae Willey \& Hickson, 1909 \\ Genus Odontochitina Deflandre, 1937}

Type species. According to Fensome et al. (2008), the nomenclatural type of the genus Odontochitina remains the holotype of Odontochitina silicorum Deflandre, 1937 (95, plate 18 (al. pl. 15), fig. 8).

\section{Odontochitina diducta sp. nov.} (P1. 6, fig. 1)

1967 Odontochitina costata Alberti, 1961; Clarke \& Verdier, pl. 13, fig. 4 only.

1991 Odontochitina operculata (Wetzel, 1933a) Deflandre \& Cookson, 1955; Heine: pl. 27, fig. 15.

1997 Odontochitina operculata (Wetzel, 1933a) Deflandre \& Cookson, 1955; Roncaglia \& Corradini: pl. 2, fig. 5.

Derivation of name. From the latin diducere, meaning to physically separate, split, referring to the high angle between the antapical and lateral horns, which are also connected via an antapical pericoel.

Diagnosis. A species of Odontochitina with a widely divergent antapical and lateral horn separated by an angle equal to or greater than $80^{\circ}$.

Holotype. MPK 13896; e/f ref: O40/3; Plate 6, fig. 1; lodged at the British Geological Survey, Kingsley Dunham Centre, Keyworth, Nottingham, UK.

Type locality and horizon. Trunch borehole, Norfolk, UK; 279.9-280.0 m, Burnham-Flamborough Chalk (undifferentiated), high Offaster pilula Zone (mid-lower Campanian).

Description. Large ceratioid, cavate dinoflagellate cyst with one apical, antapical and lateral horn of comparable length. The wall is two-layered, comprising a smooth endophragm and smooth, incompletely and faintly striate or distally perforate (although this may be due to corrosion) periphragm. The periphragm and endophragm are attached in the precingular region such that the species has a well-developed cavation connecting the lateral and antapical horns. The endocyst is sub-spherical, lacking obvious projections into the pericoel. The antapical and lateral horns are separated by an angle of greater than $80^{\circ}$. The paracingulum may be indicated by faint ridges on 
New dinoflagellate cysts from the Cenomanian to Maastrichtian, UK
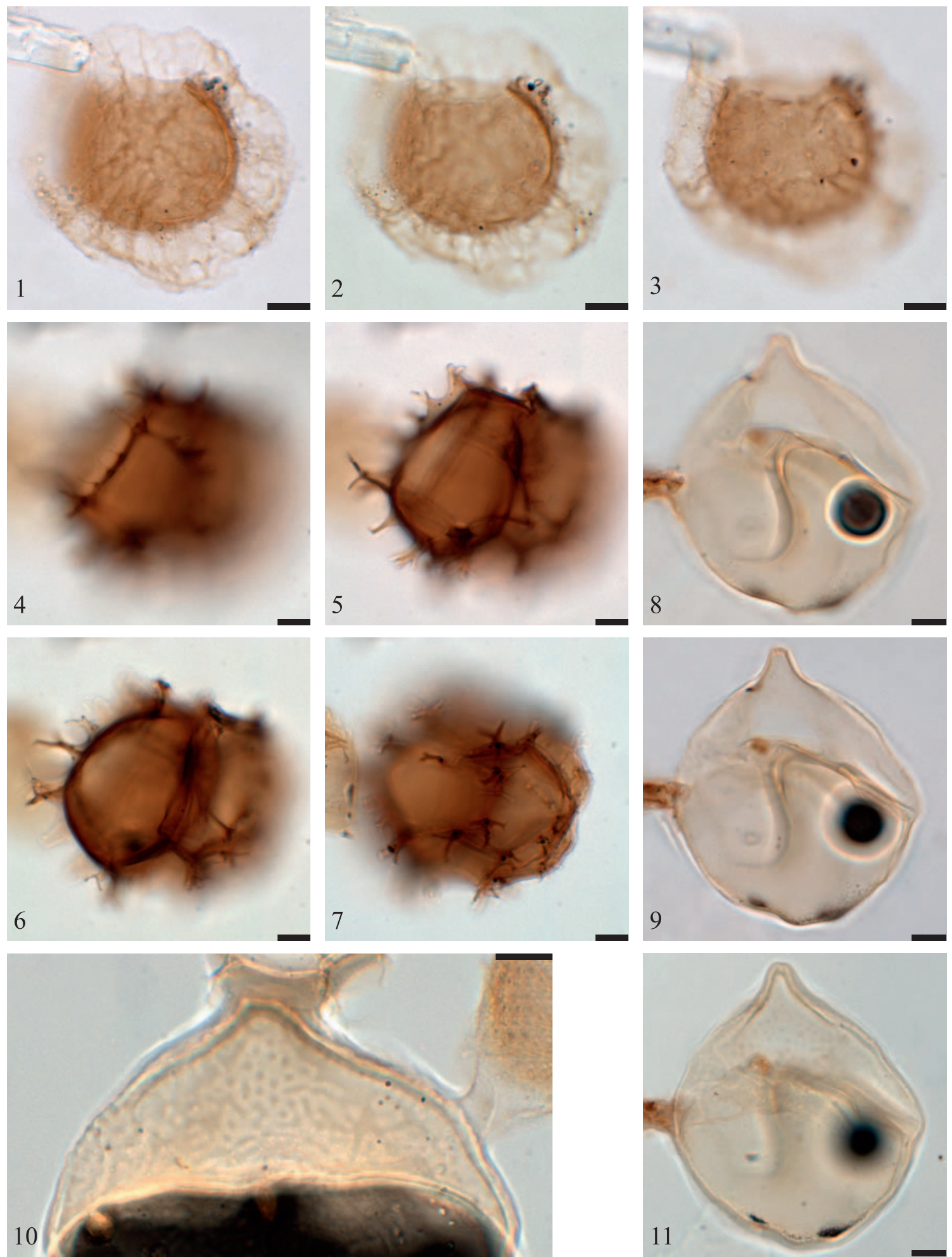

Explanation of Plate 5.

figs 1-3. Membranilarnacia wilsonii sp. nov. (holotype), MPK 13898; e/f ref. P69/1: 1, internal view (reversed); 6, external view, the ventral and dorsal surfaces have not been distinguished. figs 4-7. Hystrichostrogylon robustum sp. nov. (holotype), MPK 13890; e/f ref. P40/2: 4, internal left lateral view (reversed) showing fine spines on the archaeopyle margin; 5-6, ambital view showing the egg-shaped central body; 7, external right lateral view showing the short, robust trifurcating gonal processes. figs 8-9, 11. Nelsoniella incomposita sp. nov. (holotype), MPK 13901, e/f ref. O38/4: 8, internal dorsal view (reversed) showing the smooth periphragm; 9, ambital view showing the well-developed apical horn; 11, external ventral view showing the ornamentation on the ventral surface of the epi-periphragm; fig. 10. Nelsoniella incomposita sp. nov. (paratype), MPK 13902, e/f ref. R29/3, external ventral view showing the ornamentation on the ventral surface of the epi-periphragm. Scale bar $10 \mu \mathrm{m}$. 

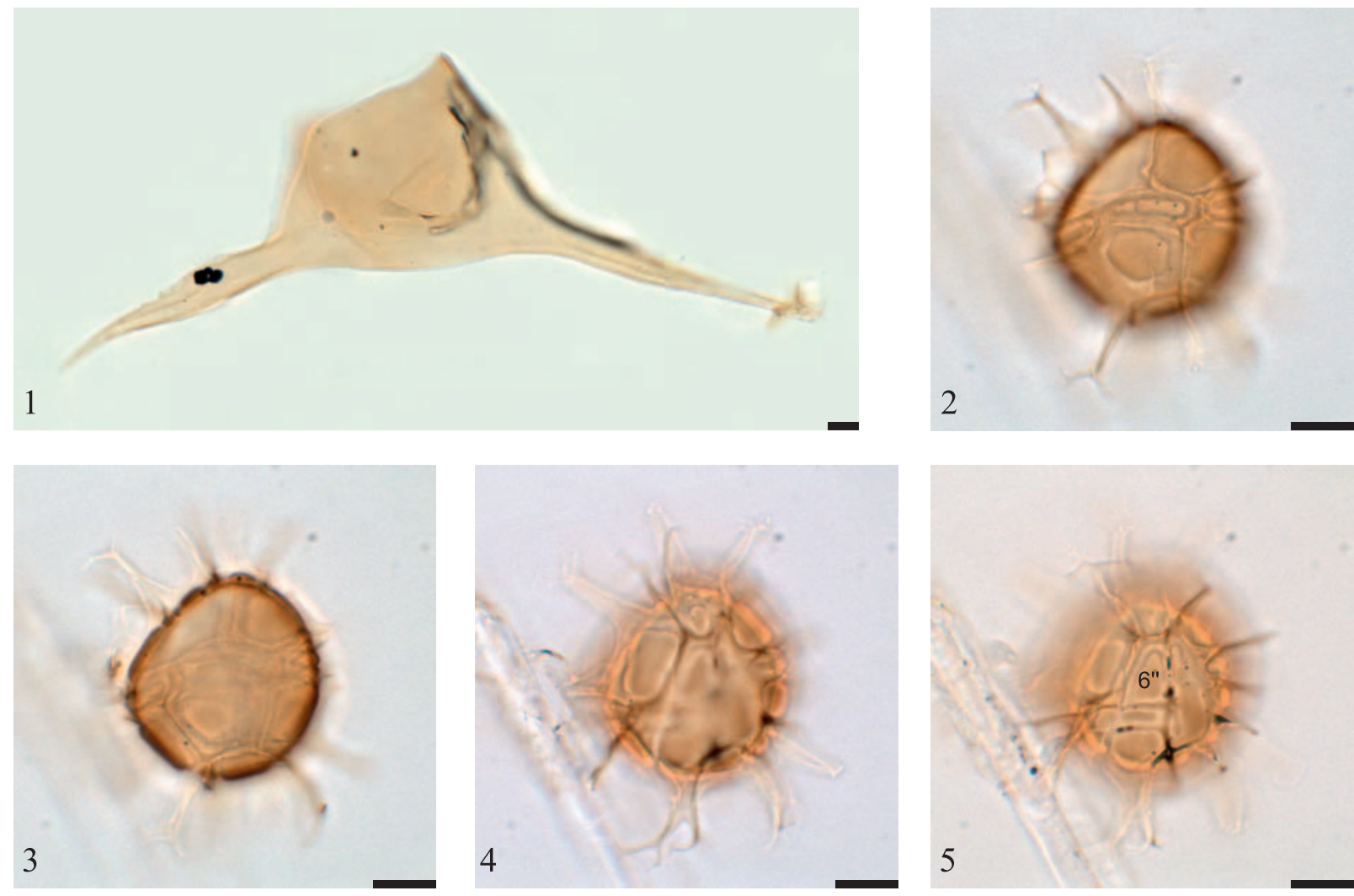

Explanation of Plate 6.

fig. 1. Odontochitina diducta sp. nov. (holotype), MPK 13896; e/f ref. O40/3, external ventral view showing the widely angle between right lateral and antapical horns and weak paracingulum. The perforations at the extremities of the horns are considered to be preservational. figs 2-5. Spiniferites jarvisii sp. nov. (holotype), MPK 13891; e/f ref. X25/2: 2, oblique internal dorsal view (reversed) showing the distinctive thinning of the endophragm; $\mathbf{3}$, ambital view showing the distinctive thinning of the endophragm; $\mathbf{4}$, oblique external mid-ventral view; $\mathbf{5}$, oblique external ventral view showing the sixth precingular paraplate. Scale bar $10 \mu \mathrm{m}$.

the periphragm. The archaeopyle is apical (Type tA, operculum detached), formed by the loss of all the apical paraplates.

Dimensions. Holotype, central body (w/l) $55 \times 50 \mu \mathrm{m}$, angle subtending lateral and antapical horns $130^{\circ}$, distance of lateral horn tip to antapical horn tip $230 \mu \mathrm{m}$; range, central body (w/l) $39(47.5) 62 \times 30(44.5) 58 \mu \mathrm{m}$, subtending lateral and antapical horns $80(122.7) 180^{\circ}$, distance of lateral horn tip to antapical horn tip 93(174.3)230 $\mu \mathrm{m} .20$ specimens measured.

Stratigraphic range. Burnham-Flamborough Chalk (undifferentiated), high Micraster coranguinum Zone (high middle Santonian) to the Sidestrand Chalk, high Belemnitella mucronata Zone (high upper Campanian; Fig. 2).

Remarks. The specimens figured by Cookson \& Eisenack (1968: 112, pl. 2, fig. D) as Odontochitina sp. and Costa \& Davey (1992, pl. 3.13, fig. 5) as Odontochitina sp. A also possess a conspicuous wide angle between the lateral and antapical horns but differ in being cornucavate, the periphragm and endophragm are appressed between.

Comparison. Differs from all other species of Odontochitina in the wide angle between the lateral and antapical horns that are also connected by the hypopericoel.

\section{Suborder Uncertain \\ Family Uncertain \\ Genus Cassiculosphaeridia Davey, 1969}

Type species. Cassiculosphaeridia reticulata Davey, 1969 (142, pl. 4, fig. 3).

Cassiculosphaeridia alta sp. nov.

(P1. 1, figs 7-9)

Derivation of name. From the latin altus, meaning high, referring to the high crests.

Diagnosis. A species of Cassiculosphaeridia with relatively high, non-tabular crests

Holotype. MPK 13897; e/f ref: P65; Pl. 1, figs 7-9; lodged at the British Geological Survey, Kingsley Dunham Centre, Keyworth, Nottingham, UK.

Type locality and horizon. Trunch borehole, Norfolk, UK; 455.9-456.0 m, Burnham-Flamborough Chalk (undifferentiated), mid-Sternotaxis plana Zone (mid-upper Turonian).

Description. Small, sub-spherical, proximate dinoflagellate cyst. The wall is single layered and composed of a smooth 
New dinoflagellate cysts from the Cenomanian to Maastrichtian, UK
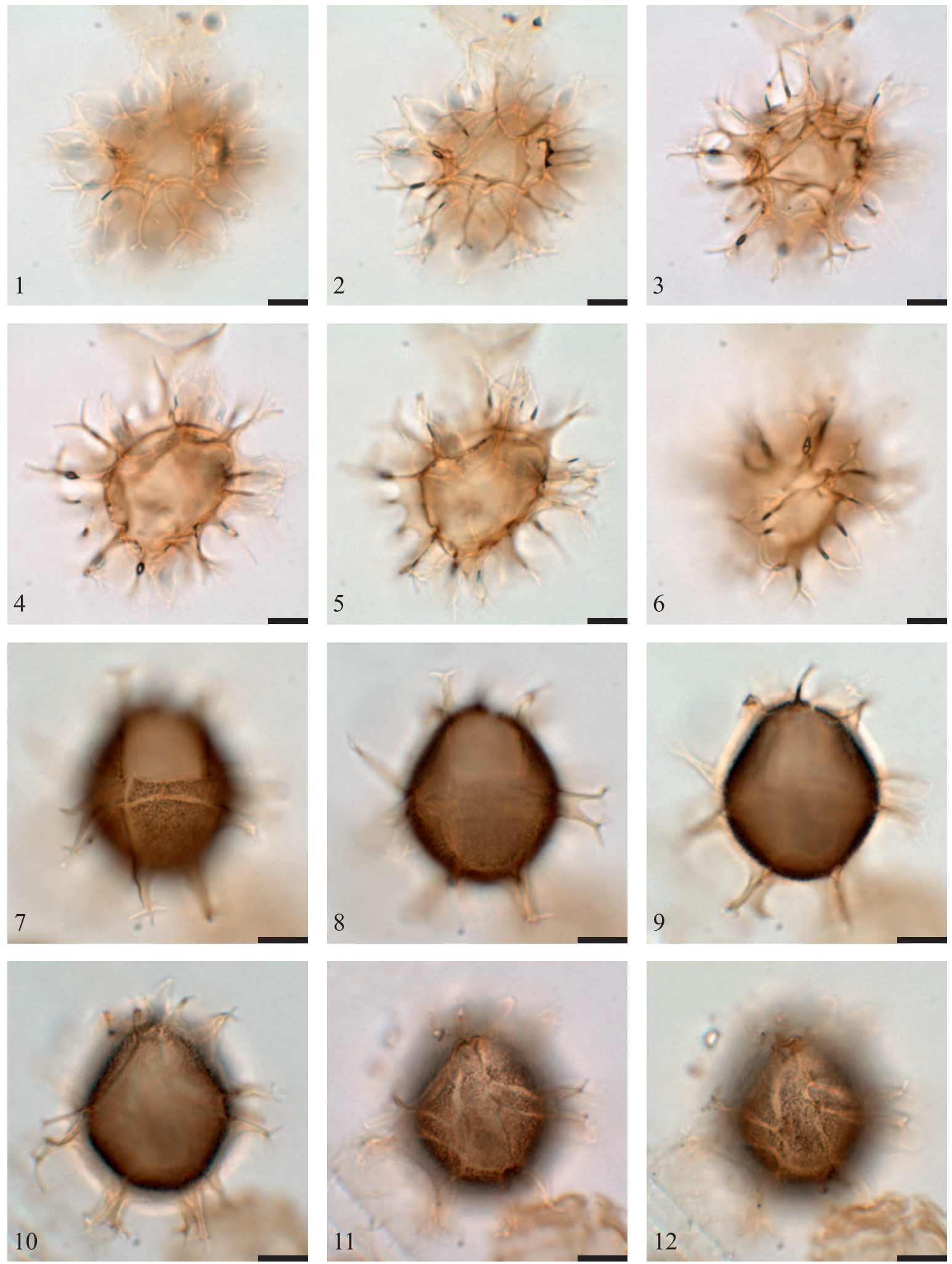

Explanation of Plate 7.

figs 1-6. Spiniferites multispinulus sp. nov. (holotype), MPK 13892; e/f ref. P48: 1, external dorsal view; 2-3, external mid-dorsal views showing paired precingular intergonal processes; 4, ambital; 5, internal mid-ventral (reversed); 6 , internal ventral view (reversed), all showing paired postcingular intergonal processes. figs 7-12. Spiniferites ramosus aquilus sp. nov. (holotype), MPK 13893; e/f ref. M56/2: 7, internal dorsal view (reversed) showing the micro-reticulate ornamentation; 8, mid-dorsal view (reversed); 9-10, ambital views showing the trifurcating gonal processes; 11, external mid-ventral view; 12, external ventral view showing the differentiated posterior sulcal paraplate. Scale bar $10 \mu \mathrm{m}$. 
autophragm that forms crests. The crests are well-developed and relatively high (up to $7 \mu \mathrm{m}$, around one-fifth of the diameter of the central body) and form a complete and irregular, typically polygonal reticulum without traces of a paratabulation. The archaeopyle is apical (Type tA, operculum detached) and formed by the loss of all apical paraplates.

Dimensions. Holotype: central body (w/l): $36 \times 36 \mu \mathrm{m}$, crest height: $6 \mu \mathrm{m}$; range: central body (w/l): $30(31.5) 36 \times$ 24(29.5)36 $\mu \mathrm{m}$, crest height: 4(5.8)7 $\mu \mathrm{m}, 5$ specimens measured.

Stratigraphic range. Ferriby Chalk, Mantellioceras mantellii Zone (lower Cenomanian) to Burnham-Flamborough Chalk (undifferentiated), low Micraster coranguinum Zone (mid-middle Coniacian; Fig. 2).

Comparison. Differs from species of Valensiella Eisenack, 1963b by lacking an ectophragm. Differs from Cassiculosphaeridia reticulata Davey, 1969 (142, pl. 3, fig. 7; pl. 4, fig. 3) as the most similar species by possessing distinctly higher crests that are stronger and consistently developed. Cassiculosphaeridia magna Davey, 1974 (46, pl. 1, figs 3-7) differs by being much larger (diameter $85-105 \mu \mathrm{m}$ ) with a particularly thick autophragm (up to $3 \mu \mathrm{m})$.

\section{Genus Membranilarnacia Eisenack, 1963b}

Type species. Membranilarnacia leptoderma (Cookson \& Eisenack, 1958: 50-51, pl. 10, fig. 9) Eisenack, 1963b.

\section{Membranilarnacia wilsonii sp. nov.}

(P1. 5, figs 1-3)

1974 Membranilarnacia 'multifibrata' Wilson: 204, pl. 33, fig. 7.

Derivation of name. In honour of Dr Graeme Wilson who first described this species as Membranilarnacia 'multifibrata' in his unpublished $\mathrm{PhD}$ thesis.

Diagnosis. A species of Membranilarnacia with a thin ectophragm supported by a large number of fine supporting processes.

Holotype. MPK 13898; e/f ref: P69/1; Plate 5, figs 1-3; lodged at the British Geological Survey, Kingsley Dunham Centre, Keyworth, Nottingham, UK.

Type locality and horizon. Trunch borehole, Norfolk, UK; 419.9-420.0 m, Burnham-Flamborough Chalk (undifferentiated), mid-Micraster cortestudinarium Zone (mid-lower Coniacian).

Description. Small to medium-sized cavate dinoflagellate with a sub-spherical central body. The central body is comprised of a thin autophragm $(\sim 0.5 \mu \mathrm{m})$ that forms numerous thin, solid, non-tabular processes that support a thin, smooth to finely reticulate ectophragm. The processes are linked proximally forming an irregular polygonal reticulum of variable size and shape. Processes not obviously concentrated on the hypocyst but where they appear to be thicker. The archaeopyle is apical (Type tA, the operculum may be attached, but more usually detached), formed by the loss of all apical paraplates.

Dimensions. Holotype, central body (w/l) $41 \times 38 \mu \mathrm{m}$, overall $(\mathrm{w} / \mathrm{l}) \quad 64 \times 62$; range, central body $(\mathrm{w} / \mathrm{l}) \quad 31(38.2) 48 \times$ 30(37.2) $47 \mu \mathrm{m}$, overall (w/1) 50(55.9)64 × 44(54)64 $\mu \mathrm{m} .14$ specimens measured.

Stratigraphic range. Burnham-Flamborough Chalk (undifferentiated), mid-Micraster coranguinum Zone (mid-lower Coniacian) to the mid-Gonioteuthis quadrata Zone (high lower Campanian; Fig. 2). Extends to the upper Maastrichtian at Stevns Klint and Karlstrup, (Denmark) according to Wilson (1974).

Comparison. Many species of Membranilarnacia possess a particularly thin ectophragm but differ from $M$. wilsonii sp. nov. by possessing stronger, better developed processes. Membranilarnacia? picena Biffi \& Manum, 1988 (190, 192, pl. 7, figs 1-3, 5-7, 9, 12) also possesses a thin veil-like ectophragm but differs in possessing a thicker spongy to externally pitted autophragm. Membranilarnacia polycladiata Cookson \& Eisenack in Eisenack (1963b) (Cookson \& Eisenack, 1958: 51, pl. 10, fig. 8) differs by possessing a thicker granular wall and processes that divide in such a way as to give a funnel-like appearance, which are more obviously concentrated on the hypocyst. Membranilarnacia? tenella Morgenroth, 1968 (554-555, pl. 48, figs 2-4) has 30-40 slender, stronger solid processes which may have tiny perforations. Membranilarnacia sp. of Kirsch (1991, pl. 26, figs 4-5) also possesses a thin ectophragm but it is supported by much shorter processes.

Order Peridiniales Haeckel, 1894

Suborder Peridiniineae (Autonym)

Family Peridiniaceae Ehrenberg, 1831

Subfamily Deflandreoideae Bujak \& Davies, 1983

Genus Alterbidinium Lentin \& Williams, 1985

Type species. According to Fensome et al. (2008), the nomenclatural type of the genus Alterbidinium remains the holotype of Alterbidinium recticorne (Vozzhennikova, 1967: 151-152, pl. 77, fig. 2) Harker \& Sarjeant in Harker et al. (1990).

Alterbidinium ioannidesii sp. nov. (P1. 1, figs 1-6)

1986 Dinoflagellate type E Ioannides: 42, pl. 23, figs 13-16.

Derivation of name. In honour of Dr Nicos Ioannides who first recorded this species as Dinoflagellate type E.

Diagnosis. A species of Alterbidinium possessing a welldeveloped parasutural paratabulation on the periphragm.

Holotype. MPK 13899; e/f ref: K38/3; Plate 1, figs 1-6; lodged at the British Geological Survey, Kingsley Dunham Centre, Keyworth, Nottingham, UK.

Type locality and horizon. Trunch borehole, Norfolk, UK; 298.9-299.0 m, Burnham-Flamborough Chalk (undifferentiated), low Offaster pilula Zone (low lower Campanian). 
Description. Medium-sized peridinioid, cornucavate to circumcavate dinoflagellate cyst. The wall is two-layered composed of a smooth endophragm and a finely reticulate to striate periphragm that forms low parasutural ridges with no accessories. The pericyst is elongate ellipsoid to biconical and forms a well-developed apical and left antapical horn (right antapical horn much reduced or absent). The endocyst is sub-spherical to ovoidal and lacks horns, follows the general shape of the pericyst and lacks supporting processes. The paratabulation is indicated by welldeveloped parasutural crests indicating the formula: 4', 3a, 7', ?c, $5^{\prime \prime \prime}, 2^{\prime \prime \prime \prime}$. The paracingulum is indicated by parallel horizontal crests, and undifferentiated, except perhaps by the most posterior paraplate in contact with the right sulcal boundary. The parasulcus is indicated by a deep longitudinal depression. The periarchaeopyle is intercalary (Type I, operculum detached) and formed by the loss of a steno-deltaform $2 \mathrm{a}$ paraplate. The endo-archaeopyle type has not been identified.

Dimensions. Holotype, overall (w/l) $42 \times 61 \mu \mathrm{m}$; range, overall $(\mathrm{w} / \mathrm{l}) 40(54.3) 62 \times 54(64.6) 74 \mu \mathrm{m} .15$ specimens measured. As recorded by Ioannides (1986), overall (w/l) 50-64 × 70-98 $\mu \mathrm{m}$, 14 specimens measured.

Stratigraphic range. Burnham-Flamborough Chalk (undifferentiated), low Offaster pilula Zone (low lower Campanian) to the low Gonioteuthis quadrata Zone (mid-lower Campanian; Fig. 2). Extends to the ?Maastrichtian at Bylot Island (Arctic Canada) according to Ioannides (1986).

Remarks. Alterbidinium ioannidesii is comparable in width to Dinoflagellate type E Ioannides, 1986 but shorter in overall length by $10-20 \mu \mathrm{m}$. Dinoflagellate type $\mathrm{E}$ has been recorded from Arctic Canada (questionably from the Maastrichtian, but no detailed occurrence data were provided) and extensively in the Norwegian Sea (pers. obs.) from the upper Santonian? to lower Campanian, often forming a common or even abundant component of the palynoflora. It is a feature of many peridinioid genera to reach a particularly large size in high (northern) latitudes (Lentin \& Williams, 1980), which are otherwise smaller elsewhere, and this may account for the slightly smaller size at Trunch.

Comparison. Differs from other species of Alterbidinium by possessing clearly developed parasutural crests on the periphragm.

Genus Chatangiella Vozzhennikova, 1967

Type species. Chatangiella niiga Vozzhennikova, 1967 (129, pl. 56, fig. 1; pl. 57, fig. 1).

Chatangiella eminens sp. nov. (Pl. 2, figs 1-6)

Derivation of name. From the latin emineo, to project, stand out, be conspicuous, remarkable, referring to the prominent paracingular spines.
Diagnosis. A species of Chatangiella possessing prominent spines on the paracingulum that are particularly well developed at the ambitus. Shorter spines are arranged in intratabular fields on the pre- and postcingular paraplates which may fuse on the margin of the pentapartite paracingulum and be randomly (but rarely) scattered elsewhere.

Holotype. MPK 13900; e/f ref: P60; Plate 2, figs 1-6; lodged at the British Geological Survey, Kingsley Dunham Centre, Keyworth, Nottingham, UK.

Type locality and horizon. Trunch borehole, Norfolk, UK; 331.9-332.0 m, Burnham-Flamborough Chalk (undifferentiated), low Uintacrinus socialis Zone (low upper Santonian).

Description. Medium-sized to large cornucavate peridinioid dinoflagellate cyst. The wall is two-layered composed of a smooth to finely granular ( $1 \mu \mathrm{m}$ thick) endophragm and a smooth to finely granular $(\sim 0.5 \mu \mathrm{m}$ thick $)$ periphragm that forms solid penitabular spines. The spines are generally $2-4 \mu \mathrm{m}$ in length, simple, evexate to capitate, longest when adjacent to paracingulum and are conspicuously long at the ambitus of the paracingulum. The spines are typically arranged in intratabular fields particularly on the pre- and postcingular paraplates and fuse on the paracingular margin where they demarcate a pentapartite paracingulum. Rare spines may also be randomly scattered over the pericyst. The pericyst is ventrodorsally compressed, longitudinally elongate, forming a short and blunt apical horn, two antapical horns (right antapical horn shorter), and a slight bulge around the paracingulum. Below the apical horn, the epicystal ambitus is convex with weakly to moderately well-developed rounded to sub-angular shoulders. From the paracingulum to the antapical horns, the ambitus of the hypocystal is concave to occasionally straight. The endocyst is sub-spherical to ovoidal, and follows the general shape of the pericyst. The left endo-antapical horn protrudes slightly into the antapical pericoel, the right endo-antapical horn is reduced. The paratabulation is incompletely indicated by the intratabular clustering of spines and the position of the archaeopyle: $\mathrm{x}^{\prime}, 3 \mathrm{a}$, 7", ?c, 5"', ?2". The parasulcus is indicated by a deep longitudinal depression. The peri-archaeopyle is intercalary (Type I, operculum detached) and formed by the loss of an iso-thetaform to iso-deltaform 2 a paraplate. The endo-archaeopyle type has not been determined.

Dimensions. Holotype, central body (w/l) $43 \times 42 \mu \mathrm{m}$, overall (w/l) $47 \times 95 \mu \mathrm{m}$, spine length (max.) $3 \mu \mathrm{m}$; range, central body $(\mathrm{w} / \mathrm{l}) 30(39.5) 44 \times 30(39.7) 50 \mu \mathrm{m}$, overall $(\mathrm{w} / \mathrm{l}) 33(43.2) 52 \times$ $52(78.9) 95 \mu \mathrm{m}$, spine length (max.) 2(2.9)4 $\mu \mathrm{m}$. 20 specimens measured.

Stratigraphic range. Burnham-Flamborough Chalk (undifferentiated), high Micraster coranguinum Zone (mid-middle Santonian) to the mid-Uintacrinus socialis Zone (low upper Santonian; Fig. 2).

Comparison. This species most closely resembles Chatangiella madura Lentin \& Williams, 1976 (see Cookson \& Eisenack, 1970, pl. 11, fig. 10) but differs by possessing longer and more strongly developed paracingular spines at the ambitus. 
Genus Nelsoniella Cookson \& Eisenack, 1960

Type species. Nelsoniella aceras Cookson \& Eisenack, 1960 (4, pl. 1, fig. 12).

Nelsoniella incomposita sp. nov.

(P1. 5, figs 8-11)

Derivation of name. From the latin incompositus, meaning irregular, disorderly, referring to the surface ornamentation.

Diagnosis. A species of Nelsoniella possessing verrucae on the ventral epitheca that may be isolated or coalesce into irregular ridges or patches.

Holotype. MPK 13901; e/f ref: O38/4; Plate 5, figs 8-9, 11; lodged at the British Geological Survey, Kingsley Dunham Centre, Keyworth, Nottingham, UK.

Paratype. MPK 13902; e/f ref: R29/3; Plate 5, fig. 10; lodged at the British Geological Survey, Kingsley Dunham Centre, Keyworth, Nottingham, UK.

Type location and horizon. Trunch borehole, Norfolk, UK; 213.9-214.0 m, Burnham-Flamborough Chalk (undifferentiated), high Gonioteuthis quadrata Zone (high lower Campanian).

Description. Large compressed sub-spherical epicavate dinoflagellate cyst with a short apical horn. The wall is two-layered, comprised of a thin (usually less than $0.5 \mu \mathrm{m}$ but up to $1 \mu \mathrm{m}$ ) and smooth to finely granular endophragm and a periphragm of variable thickness $(1-2 \mu \mathrm{m})$ being thickest at the antapex and often the apex. The periphragm is ornamented by verrucae that are either isolated or fused into discontinuous and wavy ridges with no clear or consistent pattern, generally restricted to the ventral surface of the epicyst. The endocyst is confined to the hypocyst, appressed to the periphragm in the hypocystal region and comprises one-half to two-thirds the dinocyst length, and resulting in a wide epi-pericoel. The pericyst forms a short apical horn of variable length that is often concave at the apex and may possess ridges that pass from the edge of the apical horn onto the dorsal epicyst. The peri-archaeopyle is isodeltaform with a transverse archaeopyle index of $0.4-0.5$ (as typical of genus, operculum detached). The endo-archaeopyle type has not been determined.

Dimensions. Holotype, overall (w/l) $84 \times 88 \mu \mathrm{m}$, central body (w/l) $82 \times 53 \mu \mathrm{m}$, apical horn length $6 \mu \mathrm{m}$; range, overall $(\mathrm{w} / \mathrm{l})$ $70(77.5) 86 \times 70(84.9) 101 \mu \mathrm{m}$, central body $(\mathrm{w} / \mathrm{l}) 68(75.1) 83 \times$ 31(47.9)64 $\mu \mathrm{m}$, apical horn length 3(7.8)13 $\mu \mathrm{m}$. 20 specimens measured.

Stratigraphic range. Burnham-Flamborough Chalk (undifferentiated), high Gonioteuthis quadrata Zone (high lower Campanian) to the low Belemnitella mucronata Zone (low upper Campanian; Fig. 2).

Comparison. Nelsoniella aceras Cookson \& Eisenack (1960: 4, pl. 1, figs 12-13) lacks a prominent apical horn and is deeply concave at the extreme apex, Nelsoniella oviformis Cookson \& Eisenack (1982: 33, pl. 3, fig. 2) possesses a strong apical horn but the cyst is clearly longer than broad with a weakly smooth to clearly granulated periphragm. Nelsoniella semireticulata Cookson \& Eisenack (1960: 4-5, pl. 1, fig. 15) is ornamented on the epicyst ventral surface with a low, thin-walled reticulum. Nelsoniella tuberculata Cookson \& Eisenack (1960: 4, pl. 1, fig. 14) has an epitheca ornamented with small tubercles or large granules, but which do not coalesce as frequently or as randomly as in $N$. incomposita sp. nov.

\section{Other dinocyst taxa Genus Whitecliffia gen. nov.}

Type species. Thalassiphora? spinosa (Clarke \& Verdier, 1967: 77-78, pl. 17, figs 1-2; text-fig. 31) Foucher, 1975.

Derivation of name. Named after the locality, Whitecliff (Isle of Wight, UK) where the type species was described.

Diagnosis. Laterally cavate dinoflagellate cyst formed by the separation of the periphragm and endophragm that become appressed towards the polar regions. Distinctive apical and antapical processes are developed.

Description. Medium-sized to large, laterally bicavate dinoflagellate cyst. The wall is two-layered, comprised of a thin endophragm and periphragm, which are in contact towards the apex and antapex and widely separated elsewhere. The endocyst is sub-spherical, the pericyst is sub-circular to ovoidal in plan view and broadly ovoidal in lateral view. The pericoel expands medially, prior to terminating in a rounded margin. A separation in wall layers is also apparent at the apex and antapex with the formation of processes. Four? processes conforming to paraplates $1^{\prime}-4$ ' occur at the apex and a single, wide and tubular processes conforming to paraplate $1^{\prime \prime \prime \prime}$ occurs at the antapex. Archaeopyle type has not been determined.

Comparison. Differs from Flandrecysta Slimani, 1994, Invertocysta Edwards, 1984, Lophocysta Manum, 1979, Thalassiphora Eisenack \& Gocht, 1960 and Turnhosphaera Slimani, 1994 in displaying polar, rather than dorsal-ventral, appression of the wall layers. Differs from Saturnodinium Brinkhuis et al., 1992 by possessing apical and antapical structures.

Whitecliffia spinosa (Clarke \& Verdier, 1967) gen. et comb. nov. (Pl. 8, figs 1-12)

1967 Pterospermopsis spinosa Clarke \& Verdier: 77-78, pl. 17, figs 1-2.

1973 Pterospermella spinosa (Clarke \& Verdier) Eisenack et al.: 1011-1012.

1974 Hexagonifera "perforata" sp. nov. Wilson: 279-280.

1975 Thalassiphora? spinosa (Clarke \& Verdier) Foucher: 9.

Type species. As for the genus.

Holotype. Pterospermopsis spinosa Clarke \& Verdier, 1967, pl. 17 , fig. 1 . 

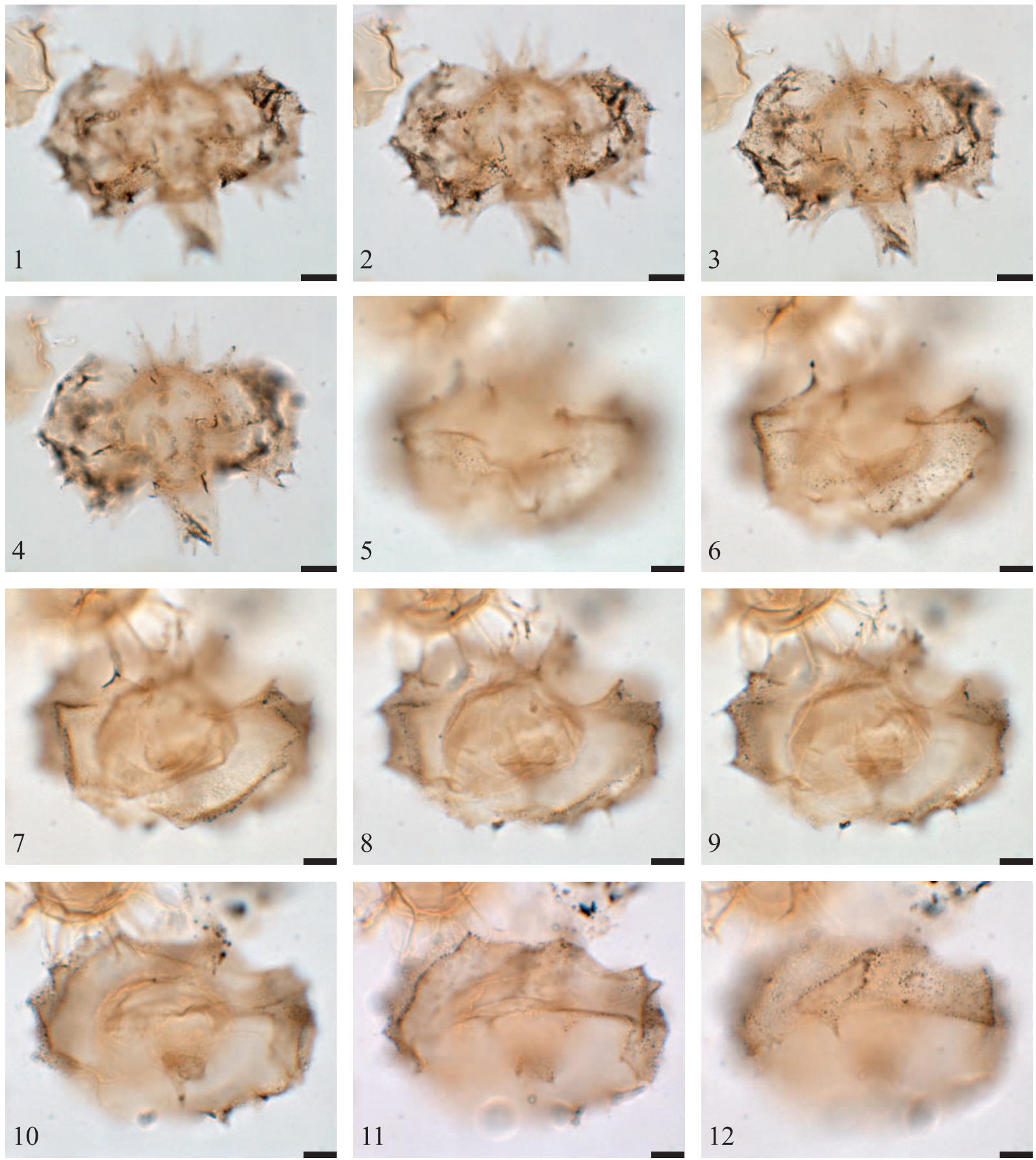

Explanation of Plate 8.

figs 1-4. Whitecliffia spinosa gen. et comb. nov.: 1, internal view (reversed); 4, external view, the ventral and dorsal surfaces have not been distinguished, showing the spines on the inflated periphragm, four apical processes and the tubular antapical process; figs 5-12. Whitecliffia spinosa gen. et comb. nov., the ventral and dorsal surfaces have not been distinguished: 5-6, internal oblique apical views showing the microreticulate to microperforate periphragm; 7, internal oblique apical view showing a possible single plate precingular archaeopyle; 8, ambital view; 9-10, external oblique antapical views showing the paracingulum; 11-12, external oblique antapical views showing the details of the antapical process. Scale bar $10 \mu \mathrm{m}$.

Locality and horizon. Culver Cliff, Isle of Wight, UK; Sample CV28, Marsupites testudinarius Zone (upper Santonian).

Supplementary description. Medium-sized to large, laterally bicavate dinoflagellate cyst. The wall is two-layered comprising a smooth and thin $(0.5 \mu \mathrm{m})$ endophragm and a smooth to microreticulate or microperforate and thin $(0.5 \mu \mathrm{m})$ periphragm. The periphragm is in contact towards the apex and antapex and widely separated elsewhere and is ornamented by non-tabular short, thorn-like acuminate spines or rarely by short processes 
with expanded tops. The endocyst is sub-spherical; the pericyst is sub-circular to ovoidal in plan view and broadly ovoidal in lateral view. The pericoel expands medially, prior to terminating in a rounded margin. A separation in wall layers is also apparent at the apex with the formation of four (or possible more) long, hollow, acuminate processes resembling a crown, and at the antapex with the formation of a wide ( $\sim 20 \mu \mathrm{m}$ wide), hollow, distally tapering, tubular process. Spines are also developed on the distal margin of the antapical process. The paracingulum is poorly expressed by two weakly developed ridges, no expression of a parasulcus has been observed. The archaeopyle type is uncertain, possibly remains attached, but may involve the one or more precingular paraplates.

Dimensions. Type material of Clarke \& Verdier (1967), holotype: overall diameter (polar view) $93 \mu \mathrm{m}$; inner body diameter $38 \mu \mathrm{m}$; length of spines 5-12 $\mu \mathrm{m}$; range: overall diameter (polar view) 85-100 $\mu \mathrm{m}$; inner body diameter $35-50 \mu \mathrm{m}$; length of spines 3-18 $\mu \mathrm{m}$ (may therefore include the antapical process).

Trunch borehole material, range: inner body (max. $\emptyset$ )

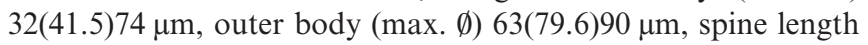
$3(4.1) 6 \mu \mathrm{m}, 1$ specimen enabled the measurement of the apical spines $(21 \mu \mathrm{m})$ and antapical process $(23 \mu \mathrm{m}), 11$ specimens measured.

Stratigraphic range. Type section, as restudied by Prince et al. (1999): Newhaven Chalk, high Uintacrinus socialis Zone (middle Santonian) to the Offaster pilula Zone (lower Campanian).

Trunch borehole material: Burnham-Flamborough Chalk (undifferentiated), mid-Offaster pilula Zone (low lower Campanian) to the Eaton-Weybourne Chalk (undifferentiated), low Belemnitella mucronata Zone (low upper Campanian; Fig. 2).

Comparison. See those for the genus.

\section{ACKNOWLEGEMENTS}

The author would like to thank the British Geological Survey for access to the Trunch borehole material and to Malcolm Jones (Palynological laboratory Service) for preparing the palynological slides. Sincere thanks go to Roger Davey, Poul Schiøler and F. John Gregory for a detailed and critical review that improved an earlier draft. Funding from Statoil ASA, Norway is gratefully acknowledged.

\section{Manuscript received 9 September 2009 Manuscript accepted 8 February 2010}

\section{REFERENCES}

Agelopoulos, J. 1964. Hystrichostrogylon membraniphorum n.g. n.sp. aus Dem Heiligenhafener Kieselton (Eozän). Neues Jahrbuch für Geologie und Paläontologie, Monatshefte, 1964: 673-675.

Alberti, G. 1961. Zur Kenntnis mesozoischer und alttertiärer Dinoflagellaten und Hystrichosphaerideen von Nord- und Mitteldeutschland sowie einigen anderen europäischen Gebieten. Paläeontographica, Abteilung A, 116: 1-58.

Below, R. \& Kirsch, K.H. 1997. Die Kerogen-Fazies der TonsteinBlättertonstein-Rhythmite des Ober-Barrême/Unter-Apt im Niedersächsischen Becken (Norddeutschland) am Beispiel der Bohrung Hoheneggelsen KB 50. Paläeontographica, Abteilung B, 242: 1-90.
Biffi, U. \& Manum, S.B. 1988. Late Eocene-Early Miocene dinoflagellate cyst stratigraphy from the Marche Region (Central Italy). Bollettino della Società Paleontologica Italiana, 27: 163-212.

Brinkhuis, H., Powell, A.J. \& Zevenboom, D. 1992. High resolution dinoflagellate cyst stratigraphy of the Oligocene/Miocene transition interval in northwest and central Italy. In: Head, M.J. \& Wrenn, J.H. (Eds), Neogene and Quaternary Dinoflagellate Cysts and Acritarchs, 219-258. American Association of Stratigraphic Palynologists, College Station, Texas.

Bujak, J.P. 1994. New dinocyst taxa from the Eocene of the North Sea. Journal of Micropalaeontology, 13: 119-131.

Bujak, J.P. \& Davies, E.H. 1983. Modern and fossil Peridiniineae. American Association of Stratigraphic Palynologists, Contributions Series, 13, 203 pp.

Bujak, J.P., Downie, C., Eaton, G.L. \& Williams, G.L. 1980. Dinoflagellate cysts and acritarchs from the Eocene of Southern England. Special Papers in Palaeontology, 24, 100 pp.

Burger, D. 1980. Palynological studies in the Lower Cretaceous of the Surat Basin, Australia. Bureau of Mineral Resources, Geology and Geophysics, Bulletin, 189: 1-106.

Bütschli, O. 1885. Erster Band. Protozoa. In Dr. H.G. Bronn's Klassen und Ordnungen des Thier-Reichs, wissenschaftlich dargestellt in Wort und Bild, 865-1088. C.F. Winter'sche Verlagsbuchhandlung, Leipzig.

Clarke, R.F.A. \& Verdier, J.P. 1967. An investigation of microplankton assemblages from the chalk of the Isle of Wight, England. Verhandelingen der Koninklijke Nederlandse Akademie van Wetenschappen, Afdeeling Natuurkunde, Eerste Reeks, 24: 1-96.

Cookson, I.C. \& Eisenack, A. 1958. Microplankton from Australian and New Guinea Upper Mesozoic sediments. Proceedings of the Royal Society of Victoria, 70: 19-79.

Cookson, I.C. \& Eisenack, A. 1960. Microplankton from Australian Cretaceous sediments. Micropaleontology, 6: 1-18.

Cookson, I.C. \& Eisenack, A. 1968. Microplankton from two samples from Gingin Brook No.4 borehole, Western Australia. Journal of the Royal Society of Western Australia, 51: 110-122.

Cookson, I.C. \& Eisenack, A. 1970. Cretaceous microplankton from the Eucla Basin, Western Australia. Proceedings of the Royal Society of Victoria, 83: 137-157.

Cookson, I.C. \& Eisenack, A. 1982. Microfossils of Australian Mezosoic and Tertiary sediments. Second part. Paläeontographica, Abteilung B, 184: $23-63$.

Costa, L.I. \& Davey, R.J. 1992. Dinoflagellate cysts of the Cretaceous System. In: Powell, A.J. (Ed.), A Stratigraphic Index of Dinoflagellate Cysts, 99-131. Special Publication of the British Micropalaeontological Society, London.

Davey, R.J. 1969. Non-calcareous microplankton from the Cenomanian of England, northern France and North America. Part I. British Museum (Natural History) Geology, Bulletin, 17: 103-180.

Davey, R.J. 1974. Dinoflagellate cysts from the Barremian of the Speeton Clay, England. In Symposium on Stratigraphic Palynology, 41-75. Birbal Sahni Institute of Palaeobotany, Special Publication, 3.

Davey, R.J. \& Verdier, J.P. 1973. An investigation of microplankton assemblages from latest Albian (Vraconian) sediments. Revista Española de Micropaleontología, 5: 173-212.

Davey, R.J. \& Williams, G.L. 1966a. The genera Hystrichosphaera and Achomosphaera. In: Davey, R.J., Downie, C., Sarjeant, W.A.S. \& Williams, G.L. (Eds), Studies on Mesozoic and Cainozoic Dinoflagellate Cysts, 28-52. British Museum (Natural History) Geology, Bulletin, Supplement, 3.

Davey, R.J. \& Williams, G.L. 1966b. The genus Hystrichosphaeridium and its allies. In: Davey, R.J., Downie, C., Sarjeant, W.A.S. \& Williams, G.L. (Eds), Studies on Mesozoic and Cainozoic Dinoflagellate Cysts, 53-106. British Museum (Natural History) Geology, Bulletin, Supplement, 3.

Deflandre, G. 1935. Considérations biologiques sur les microorganisms d'origine planctonique conservés dans les silex de la craie. Bulletin biologique de la France et de la Belgique, 69: 213-244.

Deflandre, G. 1937. Microfossiles des silex crétacés. Deuxième partie. Flagellés incertae sedis. Hystrichosphaeridés. Sarcodinés. Organismes divers. Annales de Paléontologie, 26: 51-103. 
Deflandre, G. 1939. Microplancton des mers jurassiques conservé dans les marnes de Villers-sur-Mer (Calvados). Étude liminaire et considérations générales. Station zoologique de Wimereux, Travaux, 13: $147-200$.

Deflandre, G. \& Cookson, I.C. 1955. Fossil microplankton from Australian Late Mesozoic and Tertiary sediments. Australian Journal of Marine and Freshwater Research, 6: 242-313.

Edwards, L.E. 1984. Miocene dinocysts from Deep Sea Drilling Project Leg 81, Rockall Plateau, eastern North Atlantic Ocean. Initial Reports of the Deep Sea Drilling Project, Washington, 81: 581-594.

Ehrenberg, C.G. 1831. Animalia evertebrata. In: Hemprich, P.C. \& Ehrenberg, C.G., Symbolae physicae... Pars zoologica, 10 pl. (Plates issued 1828, unpaginated text issued 1831, fide Silva, 1980b: 119.)

Ehrenberg, C.G. 1838. Über das Massenverhältniss der jetzt lebenden Kiesel-Infusorien und über ein neues Infusorien-Conglomerat als Polierschiefer von Jastraba in Ungarn. Königlich Akademie der Wissenschaften zu Berlin, Abhandlungen, 1836, 1: 109-135.

Eisenack, A. 1958. Mikroplankton aus dem norddeutschen Apt, nebst einigen Bemerkungen über fossile Dinoflagellaten. Neues Jahrbuch für Geologie und Paläontologie. Abhandlungen, 106: 383-422.

Eisenack, A. 1963a. Cordosphaeridium n.g., ex Hystrichosphaeridium, Hystrichosphaeridea. Neues Jahrbuch für Geologie und Paläontologie. Abhandlungen, 118: 260-265.

Eisenack, A. 1963b. Zur Membranilarnax-Frage. Neues Jahrbuch für Geologie und Paläontologie. Monatshefte, 1963: 98-103.

Eisenack, A. \& Cookson, I.C. 1960. Microplankton from Australian Lower Cretaceous sediments. Proceedings of the Royal Society of Victoria, 72: 1-11.

Eisenack, A. \& Gocht, H. 1960. Neue Namen für einige Hystrichosphären der Bernsteinformation Ostpreussens. Neues Jahrbuch für Geologie und Paläontologie. Monatshefte, 1960: 511-518.

Eisenack, A., Cramer, F.H. \& Diez, M.D.C.R. 1973. Katalog der fossilen dinoflagellaten, hystrichosphären und verwandten mikrofossilien. Band III. Acritarcha 1. Teil. E. Schweizerbart'sche Verlagsbuchhandlung, Stuttgart, 3: $1104 \mathrm{pp}$.

Ellegaard, M. 2000. Variations in dinoflagellate cyst morphology under conditions of changing salinity during the last 2000 years in the Limfjord, Denmark. Review of Palaeobotany and Palynology, 109: 65-81.

Fauconnier, D. \& Masure, E. 2004. Les dinoflagellés fossile. Guide pratique de détermination. Les genres à processus et à archéopyle apical. Bureau de recherche geologiques et minières (BRGM), France, $602 \mathrm{pp}$.

Fensome, R.A., Williams, G.L., Barss, M.S., Freeman, J.M. \& Hill, J.M. 1990. Acritarchs and Fossil Prasinophytes: An index to genera, species and infraspecific taxa. American Association of Stratigraphic Palynologists, Contributions Series, 25: $771 \mathrm{pp}$.

Fensome, R.A., Taylor, F.J.R., Norris, G., Sarjeant, W.A.S., Wharton, D.I. \& Williams, G.L. 1993. A Classification of Living and Fossil Dinoflagellates. Micropaleontological Press, Special Publication, 7: $351 \mathrm{pp}$.

Fensome, R.A., MacRae, R.A. \& Williams, G.L. 2008. DINOFLAJ2, Version 1. Data Series no. 1. American Association of Stratigraphic Palynologists, http://dinoflaj.smu.ca/wiki/main_page.

Foucher, J.-C. 1975. Dinoflagellés et acritarches des silex crétacés du Bassin de Paris - une synthèse stratigraphique. Annales Scientifiques de l'Université de Reims et de l'A. R.E.R.S. (Association régionale pour létude et la recherche scientifiques), 13: 8-10.

Gallois, R.W. \& Morter, A.A. 1976. Trunch Borehole, Mundesley (132) Sheet, IGS Boreholes 1975. Institute of Geological Sciences Report, 76/10: $8-10$

Haeckel, E. 1894. Systematische Phylogenie. Entwurf eines natürlichen Systems der Organismen auf Grund ihrer Stammegeschichte, I. Systematische Phylogenie der Protisten und Pflanzen. Berlin, Reimer, $\mathrm{XV}+400 \mathrm{pp}$.

Harker, S.D., Sarjeant, W.A.S. \& Caldwell, W.G.E. 1990. Late Cretaceous (Campanian) organic-walled microplankton from the interior plains of Canada, Wyoming and Texas; biostratigraphy, palaeotology and palaeoenvironmental interpretation. Paläeontographica, Abteilung B, 219: 1-243.
Heilmann-Clausen, C. \& Costa, L.I. 1989. Dinoflagellate zonation of the Uppermost Paleocene? to Lower Miocene in the Wursterheide research well, northwest Germany. Geologisches Jahrbuch Reihe A, 111: 431-521.

Heine, C.J. 1991. Late Santonian to Early Maastrichtian dinoflagellate cysts of northeast Texas. In: Thompson, L.B., Heine, C.J., Percival, S.F. \& Selznick, M.R. (Eds), Stratigraphy and micropalaeontology of the Campanian shelf in northeast Texas, 117-147. Micropalaeontology, Special Publication, 5.

Ioannides, N.S. 1986. Dinoflagellate cysts from Upper CretaceousLower Tertiary sections, Bylot and Devon Islands, Arctic Archipelago. Geological Survey of Canada, Bulletin, 371: 1-99.

Islam, M.A. 1983. Dinoflagellate cysts from the Eocene Cliff sections of the Isle of Sheppey, Southeast England. Revue de Micropaléontologie, 25: $231-250$.

Jan du Chêne, R.E., Masure, E., Belcheler, I. et al. 1986. Guide pratique pour la détermination de kystes de dinoflagellés fossiles. Le complexe Gonyaulacysta. Bulletin des Centres de Recherches Exploration-Production Elf-Aquitaine, Mémoir, 12: 1-479.

Jarvis, I., Mabrouk, A., Moody, R.T.J. \& Cabrera, S.d. 2002. Late Cretaceous (Campanian) carbon isotope events, sea-level change and correlation of the Tethyan and Boreal realms. Palaeogeography, Palaeoclimatology, Palaeoecology, 188: 215-248.

Jarvis, I., Gale, A.S., Jenkyns, H.C. \& Pearce, M.A. 2006. Secular variation in Late Cretaceous carbon isotopes: a new $\delta 13 \mathrm{C}$ carbonate reference curve for the Cenomanian-Campanian (99.6-70.6 Ma). Geological Magazine, 143: 561-608.

Kirsch, K.-H. 1991. Dinoflagellatenzysten aus der Oberkreide des Helvetikums und Nordultrahelvetikums von Oberbayern. Münchner Geowissenschaftliche Abhandlungen Reihe A, Geologie und Palaeontologie, 22: 1-306.

Klement, K.W. 1960. Dinoflagellaten und Hystrichosphaerideen aus dem unteren und mittleren Malm Südwestdeutschlands. Paläeontographica, Abteilung A, 114: 1-104.

Klumpp, B. 1953. Beitrag zur Kenntnis der Mikrofossilien des mittleren und oberen Eozän. Paläeontographica, Abteilung A, 103: 377-406.

Lamolda, M.A. \& Mao, S. 1999. The Cenomanian-Turonian boundary event and dinocyst record at Ganuza (Northern Spain). Palaeogeography, Palaeoclimatology, Palaeoecology, 150: 65-82.

Lentin, J.K. \& Williams, G.L. 1973. Fossil dinoflagellates: index to genera and species. Geological Survey of Canada, Paper, 73: 176 pp.

Lentin, J.K. \& Williams, G.L. 1976. A monograph of fossil Peridinioid dinoflagellate cysts. Bedford Institute of Oceanography, Report Series, 75: $237 \mathrm{pp}$.

Lentin, J.K. \& Williams, G.L. 1980. Dinoflagellate provincialism with emphasis on Campanian peridiniaceans. American Association of Stratigraphic Palynologists, Contributions Series, 7: $47 \mathrm{pp}$.

Lentin, J.K. \& Williams, G.L. 1985. Fossil dinoflagellates: index to genera and species, 1985 edition. Canadian Technical Report of Hydrography and Ocean Sciences, 60: $451 \mathrm{pp}$.

Lindemann, E. 1928. Abteilung Peridineae (Dinoflagellatae). In: Engler, A. \& Prantl, K. (Eds), Die Natürlichen Pflanzenfamilien nebst ihren Gattungen und wichtigeren Arten insbesondere den Nutzpflanzen. Zweite stark vermehrte und verbesserte Auflage herausgegeben von A. Engler. 2 Band, 3-104. Wilhelm Engelmann, Leipzig.

Maier, D. 1959. Planktonuntersuchungen in tertiären und quartären marinen Sedimenten. Ein Beitrag zur Systematik, Stratigraphie und Ökologie der Coccolithophorideen, Dinoflagellaten und Hystrichosphaerideen vom Oligozän bis zum Pleistozän. Neues Jahrbuch für Geologie und Paläontologie. Abhandlungen, 107: 278-340.

Mantell, G.A. 1850. A Pictorial Atlas of Fossil Remains Consisting of Coloured Illustrations Selected from Parkinson's "Organic Remains of a Former World", and Artis's "Antediluvian Phytology". Henry G. Bohn, London, xii+207pp., $74 \mathrm{pl}$.

Mantell, G.A. 1854. The Medals of Creation; or, First Lessons in Geology and the Study of Organic Remains. Henry G. Bohn, London.

Manum, S.B. 1979. Two new Tertiary dinocyst genera from the Norwegian Sea. Review of Palaeobotany and Palynology, 28: 237-248.

Mao, S. \& Lamolda, M.A. 1998. Late Cenomanian and Early Turonian dinoflagellate cysts at Ganuza Navarr I. Systematic palaeontology. Revista Española de Paleontología, 13: 261-286. 
McMinn, A. \& Burger, D. 1986. Palynology and paleoenvironments of the Toolebuck Formation, (sensu lato) in the Eromanga Basin. In: Gravestock, D.I. et al. (Eds), Contributions to the Geology and Hydrocarbon Potential of the Eromanga Basin, 139-154. Geological Society of Australia, Special Publication, 12.

Mertens, K.N., Ribeiro, S., Bouimetarhan, I. et al. 2009. Process length variation in cysts of a dinoflagellate, Lingulodinium machaerophorum, in surface sediments: Investigating its potential as salinity proxy. Marine Micropaleontology, 70: 54-69.

Morgenroth, P. 1966. Mikrofossilien und Konkretionen des nordwesteuropäischen Untereozäns. Paläeontographica, Abteilung B, 119: $1-53$.

Morgenroth, P. 1968. Zur Kenntnis der Dinoflagellaten und Hystrichosphaeridien des Danien. Geologisches Jahrbuch, 86: 533-578.

Norvick, M.S. \& Burger, D. 1976. Palynology of the Cenomanian of Bathurst Island, Northern Territory, Australia. Bureau of Mineral Resources, Geology and Geophysics, Bulletin, 151: 1-169.

Pascher, A. 1914. Über Flagellaten und Algen. Deutsche Botanische Gesellschaft, Berichte, 32: 136-160.

Peake, N.B. \& Hancock, J.M. 1961. The Upper Cretaceous of Norfolk. Transactions of the Norfolk and Norwich Naturalists' Society, 19: 293-339.

Pearce, M.A., Jarvis, I., Swan, A.R.H., Murphy, A.M., Tocher, B.A. \& Edmunds, W.M. 2003. Integrating palynological and geochemical data in a new approach to palaeoecological studies: Upper Cretaceous of the Banterwick Barn Chalk borehole, Berkshire, UK. Marine Micropaleontology, 47: 271-306.

Prince, I.M., Jarvis, I. \& Tocher, B.A. 1999. High-resolution dinoflagellate cyst biostratigraphy of the Santonian-Basal Campanian (Upper Cretaceous): New data from Whitecliff, Isle of Wight, England. Review of Palaeobotany and Palynology, 105: 143-169.

Prince, I.M., Jarvis, I., Pearce, M.A. \& Tocher, B.A. 2008. Dinoflagellate cyst biostratigraphy of the Coniacian-Santonian (Upper Cretceous): new data from the English Chalk. Review of Palaeobotany and Palynology, 150: 59-96.

Prössl, K.F. 1990. Dinoflagellaten der Kreide - Unter-Hauterive bis Ober-Turon - im niedersächsischen Becken. Stratigraphie und Fazies in der Kernbohrung Konrad 101 sowie einiger anderer Bohrungen in Nordwestdeutschland. Paläeontographica, Abteilung B, 218: 93-101.

Rawson, P.F. 1992. The Cretaceous. In: Duff, P.M.D. \& Smith, A.J. (Eds), Geology of England and Wales, 355-388. Geological Society, London.

Rochon, A., Lewis, J., Ellegaard, M. \& Harding, I.C. 2009. The Gonyaulax spinifera (Dinophyceae) "complex": Perpetuating the paradox? Review of Palaeobotany and Palynology, 155: 52-60.

Roncaglia, L. \& Corradini, D. 1997. Upper Campanian to Maastrichtian dinoflagellate zonation in the northern Appennines, Italy. Newsletters on Stratigraphy, 35: 29-57.

Sarjeant, W.A.S. 1966. Dinoflagellate cysts with Gonyaulax-type Tabulation. In: Davey, R.J., Downie, C., Sarjeant, W.A.S. \& Williams, G.L. (Eds), Studies on Mesozoic and Cainozoic Dinoflagellate Cysts, 107-157. British Museum (Natural History) Geology, Bulletin, Supplement, 3 .

Sarjeant, W.A.S. 1969. Taxonomic changes. In: Davey, R.J., Downie, C., Sarjeant, W.A.S. \& Williams, G.L. (Eds), Appendix to "Studies on Mesozoic and Cainozoic Dinoflagellate Cysts", 7-15. British Museum (Natural History) Geology, Bulletin, Appendix to Supplement, 3.

Sarjeant, W.A.S. 1985. The German Aptian dinoflagellate cysts of Eisenack (1958): A restudy. Review of Palaeobotany and Palynology, 45: 47-106.

Schiøler, P. 1993. New species of dinoflagellate cysts from Maastrichtian-Danian Chalks of the Danish North Sea. Journal of Micropalaeontology, 12: 99-112.

Schiøler, P. \& Wilson, G.J. 1993. Maastrichtian dinoflagellate zonation in the Dan Field, Danish North Sea. Review of Palaeobotany and Palynology, 78: 321-351.

Schiøler, P., Brinkhuis, H., Roncaglia, L. \& Wilson, G.J. 1997. Dinoflagellate biostratigraphy and sequence stratigraphy of the type
Maastrichtian (Upper Cretaceous), ENCI Quarry, The Netherlands. Marine Micropaleontology, 31: 65-95.

Slimani, H. 1994. Les dinokystes des craies du Campanien au Danien à Halembaye, Turnhout (Belgique) et à Beutenaken (Pays-Bas). Mémoires pour servir à l'explication des cartes Géologiques et Minières de la Belgique, 37: 1-173.

Slimani, H. 2001. New species of dinoflagellate cysts from the Campanian-Danian Chalks at Hallembaye and Turnhout (Belgium) and at Beutenaken (The Netherlands). Journal of Micropalaeontology, 20: $1-11$.

Stover, L.E. 1977. Oligocene and Early Miocene dinoflagellates from Atlantic corehole 5/5B, Blake Plateau. American Association of Stratigraphic Palynologists, Contributions Series, 1: 66-88.

Stover, L.E. \& Evitt, W.R. 1978. Analyses of pre-Pleistocene organicwalled dinoflagellates. Stanford University Publications, Geological Sciences, 15: $300 \mathrm{pp}$.

Stover, L.E. \& Williams, G.L. 1995. A revision of the Paleogene dinoflagellate genera Areosphaeridium Eaton 1971 and Eatonicysta Stover and Evitt 1978. Micropaleontology, 41: 97-141.

Taylor, F.J.R. 1980. On dinoflagellate evolution. BioSystems, 13: 65-108.

Thomsen, E. \& Heilmann-Clausen, C. 1985. The Danian-Selandian boundary at Svejstrup with remarks on the biostratigraphy of the boundary in the Western Denmark. Geological Society of Denmark, Bulletin (Meddelelser Fra Dansk Geologisk Forening), 33: 341-362.

Thurow, J., Moullade, M., Brumsack, H.-J., Masure, E., Taugourdeau-Lantz, J. \& Dunham, K. 1988. The CenomanianTuronian boundary event (CTBE) at Hole 641A, ODP Leg 103 (Compared with the CTBE interval at Site 398). Proceedings of the Ocean Drilling Program, Scientific Results, College Station, Texas, 103: $587-634$

Uutela, A. 1989. Age and dispersal of sedimentary erratics on the coast of southwestern Finland. Geological Survey of Finland, Bulletin, 349: $1-10$.

Vozzhennikova, T.F. 1967. Iskopaemye peridinei Yurskikh, Melovykh $i$ Paleogenovykh otlozheniy SSSR. Izdatelstvo Nauka, Moscow, 347 pp.

Wetzel, O. 1933a. Die in organischer Substanz erhaltenen Mikrofossilien des baltischen Kreide-Feuersteins mit einem sedimentpetrographischen und stratigraphischen Anhang. Paläeontographica, Abteilung A, 77: 141-186.

Wetzel, O. 1933b. Die in organischer Substanz erhaltenen Mikrofossilien des baltischen Kreide-Feuersteins mit einem sedimentpetrographischen und stratigraphischen Anhang. Paläeontographica, Abteilung A, 78: 1-110.

Whatley, R.C., Pyne, R.S. \& Wilkinson, I.P. 2003. Ostracoda and palaeo-oxygen levels, with particular reference to the Upper Cretaceous of East Anglia. Palaeogeography, Palaeoclimatology, Palaeoecology, 194: 355-386.

Willey, A. \& Hickson, S.J. 1909. The Protozoa (continued). Section F. The Mastigophora. In: Lankester, R. (Ed.), A Treatise on Zoology. Part 1. Introduction and Protozoa. First Fascicle, 154-192. Adam \& Charles Black, London (reprinted by A. Asher, Amsterdam, 1964).

Williams, G.L. \& Downie, C. 1966. Further dinoflagellate cysts from the London Clay. In: Davey, R.J., Downie, C., Sarjeant, W.A.S. \& Williams, G.L. (Eds), Studies on Mesozoic and Cainozoic Dinoflagellate Cysts, 215-235. Bulletin of the British Museum (Natural History), Geology, Supplement, 3.

Wilson, G.J. 1974. Upper Campanian and Maastrichtian Dinoflagellate Cysts from the Maastricht Region and Denmark. PhD thesis, University of Nottingham, $601 \mathrm{pp}$.

Wood, C.J., Morter, A.A. \& Gallois, R.W. 1994. Appendix 1. Upper Cretaceous stratigraphy of the Trunch borehole. TG23SE8. In: Arthurton, R.S., Booth, S.J., Morigi, A.N., Abbott, M.A.W. \& Wood, C.J. (Eds), Geology of the Country around Great Yarmouth. Memoir for 1:50,000 Sheet 162 (England and Wales) with an Appendix on the Trunch Borehole by Wood and Morter, 105-110. HMSO, London.

Yun, H.-S. 1981. Dinoflagellaten aus der Oberkreide (Santon) von Westfalen. Paläeontographica, Abteilung B, 177: 1-89. 